\title{
Analysis of slope stability hazards along hilly highways: Ain Sukhna- Zafarana highway, North Galala Plateau, Eastern Desert, Egypt
}

\author{
W. A. M. Ogila ${ }^{1}$, S. Abdeltawab ${ }^{1}$, A. M. Abdelkader ${ }^{1}$, M. Yousef ${ }^{1}$ \\ ${ }^{1}$ Geology Department, Faculty of Science, Ain Shams University, Cairo, Egypt.
}

\section{ARTICLE INFO}

Received 24 November 2021

Accepted 02 January 2022

Keywords

Slope instability,

North Galala,

Kinematic and deterministic

analyses,

Rockfall analysis,

Slope protection.

Correspondence

W. A. M. Ogila

E-mail

walid_ogala@sci.asu.edu.eg

\section{A BSTRACT}

A part of the eastern side of the North Galala plateau is subjected to intense slope stability hazards. The present study aims at assessing and analyzing the different slope failures along the North Galala plateau and predicting the failure types through their kinematic/deterministic and rockfall analyses, followed by the suggestion of mitigation and supporting measures for the unstable zones. The slope rock masses consist of the Paleozoic interbedded rock units of sandstone and claystone at the base and the Cretaceous-Eocene carbonate rock units at the top.

Assessment and analysis of rock masses revealed that the studied area shows, planar, wedge, and toppling failures which are controlled mainly by the unfavorable discontinuities. Kinematic analysis of the studied discontinuities with the slope angles and orientations identifies the occurrence of these slope failures through the steeper segments of each slope profile. Deterministic analysis and calculated factor of safety (FS) show that the most studied rock slope discontinuities are stable under both dry static and dynamic condition, and their stability condition is significantly reduced in saturated conditions where the calculated FS is frequently less than unity. Rockfall simulation is constructed at ravelling zones to assess the block trajectories, runout distance, kinetic energy, and bounce profiles of the falling blocks. Supporting and mitigation measures are recommended based on the slope stability analysis, site inspection, and encountered engineering geological conditions of different rock masses.

\section{Introduction}

The studied area lies in the eastern side of the North Galala plateau, it is located in the northwestern part of the Gulf of Suez rift and bounded by longitudes $32^{\circ} 22^{\circ}$ $30^{\prime \prime}$ and $32^{\circ} 28^{\prime} 45^{\prime \prime} \mathrm{E}$, and latitudes $29^{\circ} 25^{\prime} 00^{\prime \prime}$ and $29^{\circ} 30^{\prime} 00^{\prime}$ N, Fig. 1. This area is currently being subjected to intense new urban development along the Ain Sukhna-Zafarana highway. These developments include urbanizations, widening of the existing roads, and construction of new roads and tunnels particularly along the coastal and plateau area.
The mass excavation is carried out for road constructions along the natural slopes of the eastern side of the North Galala plateau. Generally, the improper expansion of such activities, which aims at modifying the natural slope gradients and widening the road by blasting and breakage, exposes inherent discontinuities and develops new tension cracks, which further affect the stability of the studied slopes. Choosing the appropriate excavation method is the most significant consideration in highway and foundation designs. Random excavation activities can 
negatively affect slope stability particularly in hilly mountain areas, which can result in some rock failures due to the presence of unfavorable discontinuities. Not only does this threaten people's safety on the road, but it also destroys both property and the environment ${ }^{[1]}$. Slope instability can occur as the result of either natural factors, e.g. groundwater level, rainfall $[2,3]$, and snowfall, or man-made factors, e.g. mining, roads, and housing constructions ${ }^{[4-6]}$. Hence, accurate assessment of slope stability plays a key role in maintaining people's safety, saving natural resources, and avoiding economic losses ${ }^{[7,8]}$.

From the slope stability point of view, most natural rock slopes are in equilibrium, where the rock mass shear strength is usually greater than the downward gravitational force. However, excavation activities cause modifications in force distribution posing the risk of slope failure ${ }^{[9]}$. In addition, the presence of water resulting from rainfall and/or human activities leads to the increase of this potential failure ${ }^{[10]}$ due to the loss of shear strength and cohesion properties along the discontinuity planes ${ }^{[11]}$. Basically, slope instability is controlled by the properties of unfavorable discontinuities with respect to the cut slope orientation ${ }^{[12]}$. These rock failures are induced when the slope's downward driving force exceeds the rock mass resisting force along the sliding surfaces [13]. These rock failures along cut slopes can be extremely dangerous on road infrastructures and highway traffic.

The Ain Sukhna-Zafarana highway is a high-traffic road that connects the Cairo capital with several cities along the Red Sea coast. However, based on field investigations, kinematic and deterministic analyses, and rockfall simulation; parts of this road are potentially hazardous. Hence, this paper aims at i) assessing the existing cut slopes stability to study the possible different slope failures and analyze each type, ii) subdividing the study area into low-, moderate- and high-risk zones of rockfall and other landslide hazards, and iii) determining the types of stabilization and protection measures required for the enforcement of the unstable zones to ensure the long-term stability and safety of the existing cut slopes.

\section{Material and methods}

Prior to the assessment of the engineering geological properties of the study area and their impact on the urban planning at Ain Sukhna coastal strip (North
Galala plateau), detailed field geological and engineering geological mapping of the investigated area was carried out. Different types of discontinuities in the rock masses were measured, as well as the orientations of the tectonic and non-tectonic fractures in the rock units, which can have serious implications for geo-hazard and related engineering problems that negatively affect infrastructure planning.

Slope stability was assessed using kinematic and deterministic analyses, and rockfall simulation. Kinematic analysis is used through stereographic projection to predict the failure mechanisms along the existing rock cut slopes through Rocscience ${ }^{\mathrm{TM}}$ Dips V. (6.008) software. Moreover, the factor of safety (FS) for each expected slope failure is calculated by the deterministic analysis using available computer softwares such as Rocscience ${ }^{\mathrm{TM}}$ RocPlane (v. 2.029), and Rocscience ${ }^{\mathrm{TM}}$ SWedge (v. 4.080). Rockfall simulation is carried out at ravelling zones to assess the characteristics of falling rock blocks using Rocscience ${ }^{\mathrm{TM}}$ RocFall (v. 4.058) software for barrier design considerations.

\section{Geological setting}

Prior to the assessment of the slope stability hazards in the study area and their impact on urban planning, an essential first step involves the delineation of the detailed geology of the investigated area in order to achieve an extensive result. The geological and geotechnical parameters have significant variabilities throughout the stratigraphic succession of North Galala Plateau rock masses. In addition, it is important to outline the orientations and other field observations (such as attitude, presistance, roughness, strength, and water condition) of the dominant weakness planes ((bedding planes, joints, fractures, and faults) within the rock masses.

\subsection{Stratigraphy}

The exposed stratigraphic rock units throughout the study area are dominated by Upper Paleozoic, Mesozoic and Cenozoic exposures, Fig. 2. The Upper Paleozoic strata are represented by the Aheimer Formation and the lower part of Qiseib Formation [14], while the upper part of Qiseib Formation represents the Triassic strata ${ }^{[15]}$. The Mesozoic rock units are of Cretaceous age and are referred to as Malha and Galala Formations as well as the Wata Formation from older 
to younger formations, respectively ${ }^{[15,16]}$. The Upper Jurassic strata are not exposed in the study area. The Lower Eocene strata represented by Thebes and Minia Formations ${ }^{[17]}$, unconformably overlie the older rocks in the study area, Fig. 2. Oligo-Miocene basaltic dykes were found intruding older strata ${ }^{[18]}$. Quaternary sediments are the most recent deposits within the study area.

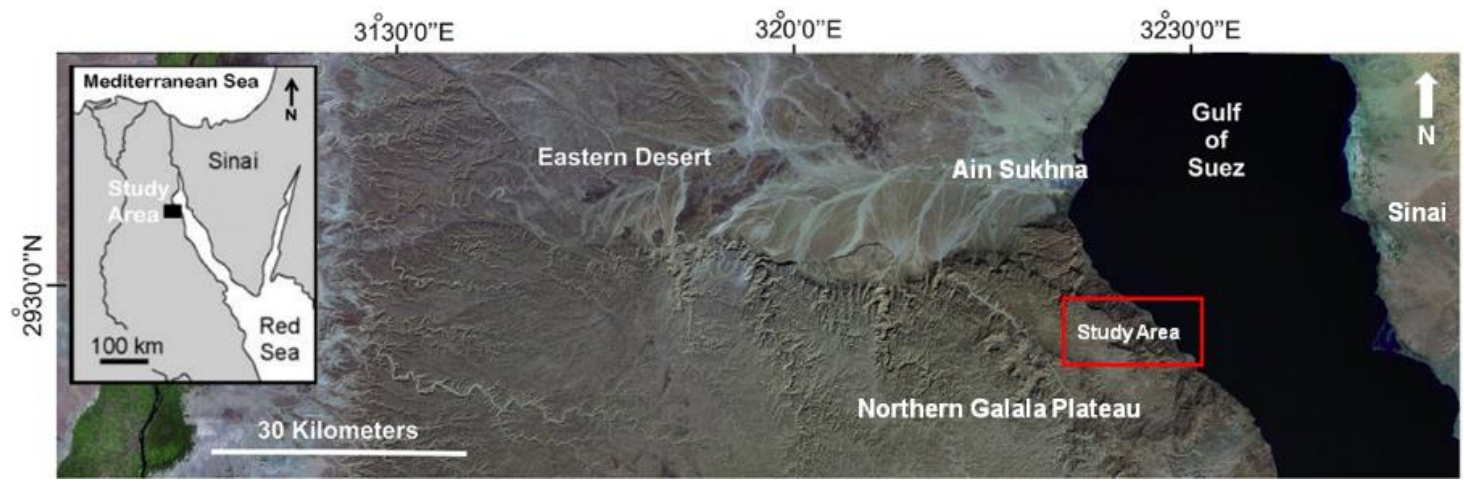

Fig. 1 Location map of the study area

\begin{tabular}{|c|c|c|c|c|c|c|}
\hline \multicolumn{3}{|c|}{ Age } & Rock Unit & Lithology & Description & $\begin{array}{l}\text { Thickness } \\
{[\mathrm{m}]}\end{array}$ \\
\hline \multirow{3}{*}{ 莀 } & \multicolumn{2}{|r|}{ Quatemary } & $\begin{array}{c}\text { Wadi } \\
\text { alluvium }\end{array}$ & & $\begin{array}{l}\text { Mixtures of sand, silt and clay with } \\
\text { gravels of different sizes. }\end{array}$ & - \\
\hline & \multirow{2}{*}{ 总 } & \multirow{2}{*}{ Early Eocene } & $\begin{array}{l}\text { Minia } \\
\text { Formation }\end{array}$ & 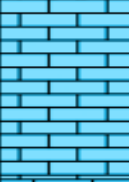 & $\begin{array}{l}\text { White to light grey, hard, massive, } \\
\text { fossiliferous, argillaceous limestone and } \\
\text { dolomitic limestone with thin beds of } \\
\text { dolomite and laminated chalky limestone } \\
\text { at intervals. }\end{array}$ & 130 \\
\hline & & & $\begin{array}{l}\text { Thebes } \\
\text { Formation }\end{array}$ & 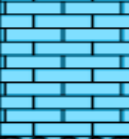 & $\begin{array}{l}\text { White, hard, thick-bedded, limestone } \\
\text { with some nodules and bands of chert at } \\
\text { some intervals. }\end{array}$ & 145 \\
\hline \multirow{4}{*}{$\frac{.}{\frac{0}{0}}$} & \multirow{2}{*}{ 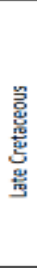 } & Turonian & $\begin{array}{l}\text { Wata } \\
\text { Formation }\end{array}$ & 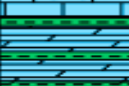 & $\begin{array}{l}\text { Grey to light grey, thick-bedded, hard, } \\
\text { dolomite, dolomitic limestone and chalky } \\
\text { limestone with interbeds of varicolored } \\
\text { shale. }\end{array}$ & 60 \\
\hline & & Cenomanian & $\begin{array}{l}\text { Galala } \\
\text { Formation }\end{array}$ & $-=-$ & $\begin{array}{l}\text { Intercalated yellow calcarcous marl and } \\
\text { green shale with thin sandstone beds. }\end{array}$ & 129 \\
\hline & 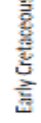 & Aptian - Albian & $\begin{array}{l}\text { Malha } \\
\text { Formation }\end{array}$ & $+-\overline{-c-1}$ & $\begin{array}{l}\text { Bright purple to red, medium to fine } \\
\text { grained sandstone with kaolinitic clay } \\
\text { interbeds. }\end{array}$ & 106 \\
\hline & 惫 & Permo - Triassic & $\begin{array}{l}\text { Qiseib } \\
\text { Formation }\end{array}$ & $--\overline{--}$ & $\begin{array}{l}\text { Red to reddish brown, fine to coarse } \\
\text { grained sandstone with variegated } \\
\text { claystone and siltstone. }\end{array}$ & 65 \\
\hline \multirow{4}{*}{ 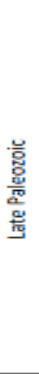 } & 䟫 & \multirow{4}{*}{ 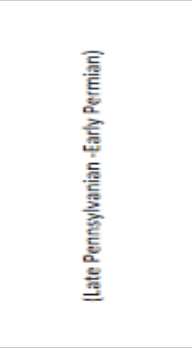 } & \multirow{4}{*}{$\begin{array}{l}\text { Aheimer } \\
\text { Formatiom }\end{array}$} & & \multirow{2}{*}{$\begin{array}{l}\text { Upper member made up of friable to } \\
\text { semi friable thick-bedded white } \\
\text { sandstone and thin bedded and cross } \\
\text { bedded, vellowish brown sandstone with } \\
\text { few light grey siltstone interbeds }\end{array}$} & \multirow{4}{*}{250} \\
\hline & \multirow{3}{*}{ 产 } & & & 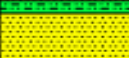 & & \\
\hline & & & & 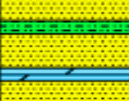 & $\begin{array}{l}\text { Middle member made up of vellowish } \\
\text { brown sandstone intercalated with few } \\
\text { dark to light grey siltstone and thin, hard } \\
\text { carbonate beds at the base. }\end{array}$ & \\
\hline & & & & $=-\overline{-}$ & $\begin{array}{l}\text { Lower member made up of alternating } \\
\text { bands of dark grrey, dark olive green and } \\
\text { black unfossiliferous fissile shale with } \\
\text { calcareous sandstone and siltstone beds. }\end{array}$ & \\
\hline & & & $\equiv \equiv \mathrm{Ma}$ & & Shale and claystone & salt \\
\hline & & $\begin{array}{l}\text { ornite and } \\
\text { omitic limestone }\end{array}$ & $\cdots s$ & Astone E: & Siltstone & $\begin{array}{l}\text { di } \\
\text { uvium }\end{array}$ \\
\hline
\end{tabular}

Fig. 2 Composite stratigraphic section of the study area (compiled from ${ }^{[14,15,17,18,19,20]}$ ) 


\subsection{Structures}

The study area is affected by multiple phases of complex deformation that are characterized by the abundance of different fracture sets. These fractures are in general following the major trends of the regional tectonic framework of the area and its vicinity. Normal faults and associated joints on minor and major scales are the most dominant structural features observed during field mapping and measurements, Fig. 3. The fault systems are subdivided according to the degree of abundance into three main sets, which are oriented northwest, northeast, and north-south in a descending order. The dip angles for these faults range between $54^{\circ}$ to $75^{\circ}$ which are considered as moderate to high dip angles. These faults dissect the exposed strata of Carboniferous, Permo-Triassic, Cretaceous, and Eocene ages throughout the investigated area, Fig. 3. The main dip direction of most of the mapped faults is due to northeast. However, some of these faults have opposite directions of throws and dips (e.g. $F_{1}$ and $F_{4}$; $F_{5}$ and $F_{6}$ ) particularly at the northwestern part of the study area, forming horsts and grabens, Fig. 3. Moreover, one of these major faults is a listric normal fault $\left(F_{7}\right)$, forming a rollover anticline on the hanging wall block. On the other hand, at the northern part of the study area several exposures of the basaltic dykes are observed along two major fault planes ( $F_{6}$ and $\left.F_{12}\right)$ and intersect with other faults (e.g. $F_{7}$ ), Fig. 3. During field mapping, a fault block is observed along the footslope of the coastal strip in the northeastern part. This block is bounded by two faults $\left(F_{2}\right.$ and $\left.F_{3}\right)$, where the Cretaceous and Permo-Triassic strata are juxtaposed against the Paleozoic rocks, Fig. 3.

\section{Rock mass properties and classification}

The exposed rock units in the study area are categorized using Rock Mass Rating (RMR) classification ${ }^{[21]}$, Table 1 and Fig. 3. This classification comprises the study of many parameters such as intact rock strength, volumetric rock quality designation (RQD), discontinuity properties, groundwater conditions, and weathering degree. The measured values of the different RMR parameters for each rock mass, as well as the classes of RMR parameters and classification of different rock units in the study area are represented in Table 2 and Fig. 3.
The discontinuity properties are governed by some significant parameters such as sets, orientation, spacing, persistence, infilling materials, aperture, roughness, friction angle and water seepage [22] which control overall rock mass behaviors. Based on RMR classification, specifically in dry groundwater conditions, the rock mass quality of the studied sandstone, limestone, dolomitic limestone and other dolomite rocks are good rocks (class II), since the surface is dry. However, the marl is fair rocks (III) which is occasionally present.

\section{Slope stability analysis}

Stability analysis of rock slopes is a very important approach in the engineering geological investigation [23] during and after slope excavation operation. Commonly, during excavation of rock cut slopes in different rock types, failures are frequently controlled by the occurrence of geological discontinuities; e.g., faults, shear zones, bedding planes, joints, etc. ${ }^{[24]}$. The intersection patterns of these discontinuities with respect to the slope orientation led to the development of rock slabs, blocks, or wedges that can fall or slide from the face of the excavation. In these cases, slope failure is frequently a geo-hazard, where deformations and failures are caused by sliding along an individual discontinuity surface or along lines of intersection of planes of weakness formed by one or several sets within the rock mass. Many methods are available to predict the stability problems of rock slope sections including the limit equilibrium method (LEM) ${ }^{[25] .}$

Stability analyses of rock slopes in the investigated area have been studied in detail along the existing rock cut slopes. The locations of potential slope failures have been identified based on field observations during the engineering geological mapping. In order to assess the stability of the existing rock cut slopes, the kinematic and deterministic analyses were initially carried out. These analyses were selected to understand each failure type mechanism and calculate its factor of safety (FS), then propose the appropriate method for stabilizing unstable sections. 


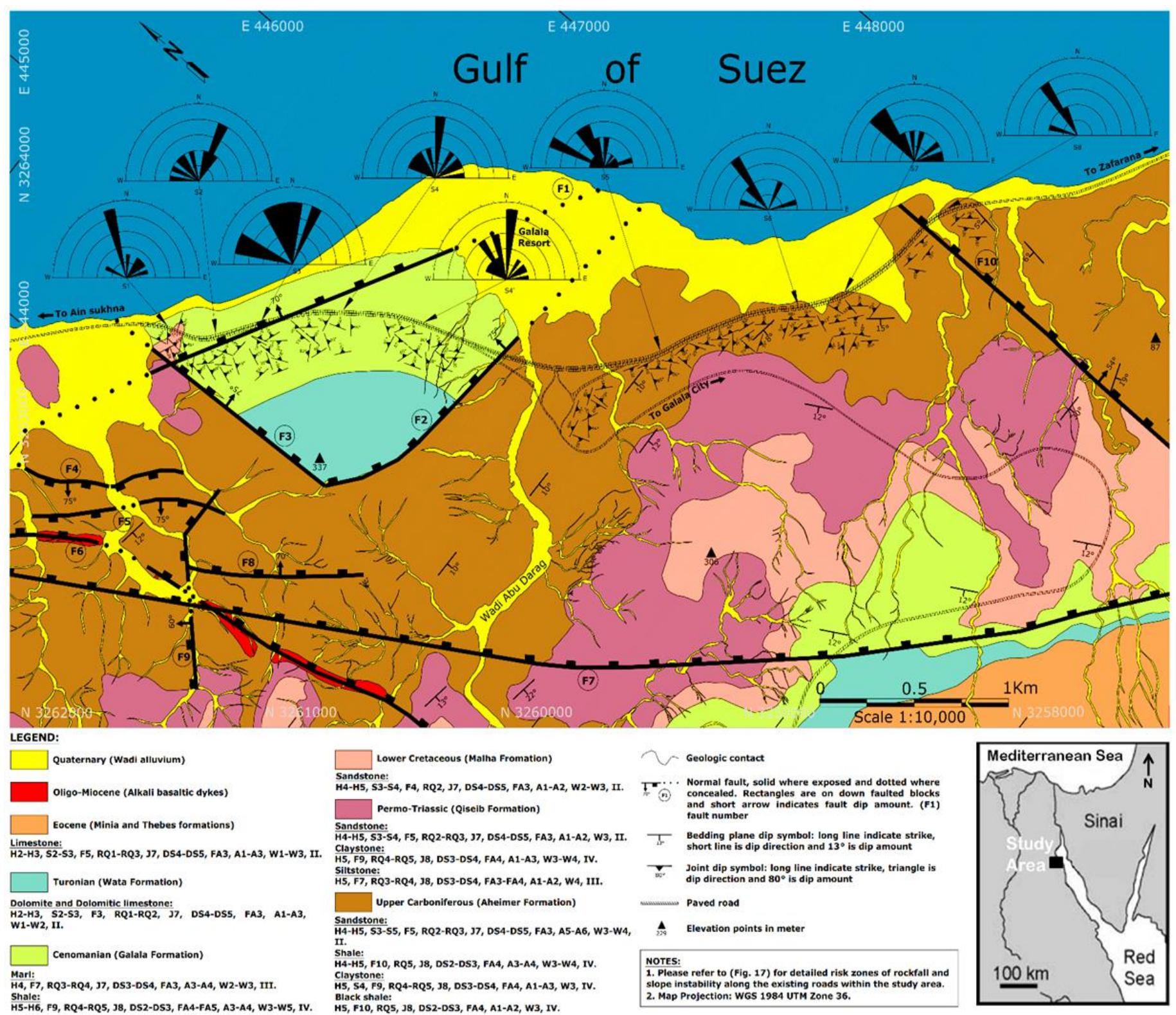

Fig. 3 Engineering geological map of the study area showing the dominant joint sets (rose diagrams) and rock mass properties

\subsection{Discontinuity survey}

A detailed discontinuity survey was carried out on nine rock cuts along Ain Sukhna-Zafarana highway at Wadi Abu Darag area, Figs. 4 and 5. The dominant discontinuities, that affect the rock masses through the coastal strip and their surrounding resorts area are faults, joints, and bedding planes. The attitudes (dip amount and dip direction) of these structural elements are measured using the scanline technique following the right-hand rule. A total of 1638 joint planes were measured at nine locations along the excavated slopes, Fig. 4. These joint sets affect essentially the excavated slopes made up of Paleozoic interbedded sandstone and claystone, and black shale in the lower part as well as
Cretaceous sandstone, green shale, and marl at the upper part. The data analysis of the field measured discontinuities indicates the existence of five joint sets, Fig. 3. According to the degree of predominance, these joint sets are oriented NW to NNW, N-S, WNW, NE to ENE, and E-W, Fig. 3. The dip amounts of the measured discontinuities vary between gentle, moderate, steep, very steep and vertical with angles ranging between $10^{\circ}$ for bedding planes and up to $90^{\circ}$ for other joints. Most of these discontinuities have closed apertures. However, some occasionally have open aperture that ranges from 0.5 $\mathrm{cm}$ to $4 \mathrm{~cm}$, (with an average of about $2.25 \mathrm{~cm}$ ). The wall surfaces of the studied discontinuities are mostly smooth to slightly rough with slickenside striation, completely dry, slightly 
weathered with no sign of alteration and infilling. The joint spacing of the NW to NNW, WNW, and NNE to ENE sets ranges between $0.1 \mathrm{~m}$ (highly fractured rocks) and $4 \mathrm{~m}$ (slightly fractured rocks). While the joints spacing of the N-S joint set ranges from $0.1 \mathrm{~m}$ (highly fractured rocks) to $10 \mathrm{~m}$ (very slightly fractured rocks) and the E-W joint set ranges between $0.1 \mathrm{~m}$ (highly fractured rocks) and $2 \mathrm{~m}$ (slightly fractured rocks), please refer to Table 1 and Fig. 3 for more details. The persistence of all measured discontinuities exceeds $10 \mathrm{~m}$ which is considered very long.

Table 1 Rock Mass Rating System, RMR classification system, (modified after ${ }^{[21]}$ )

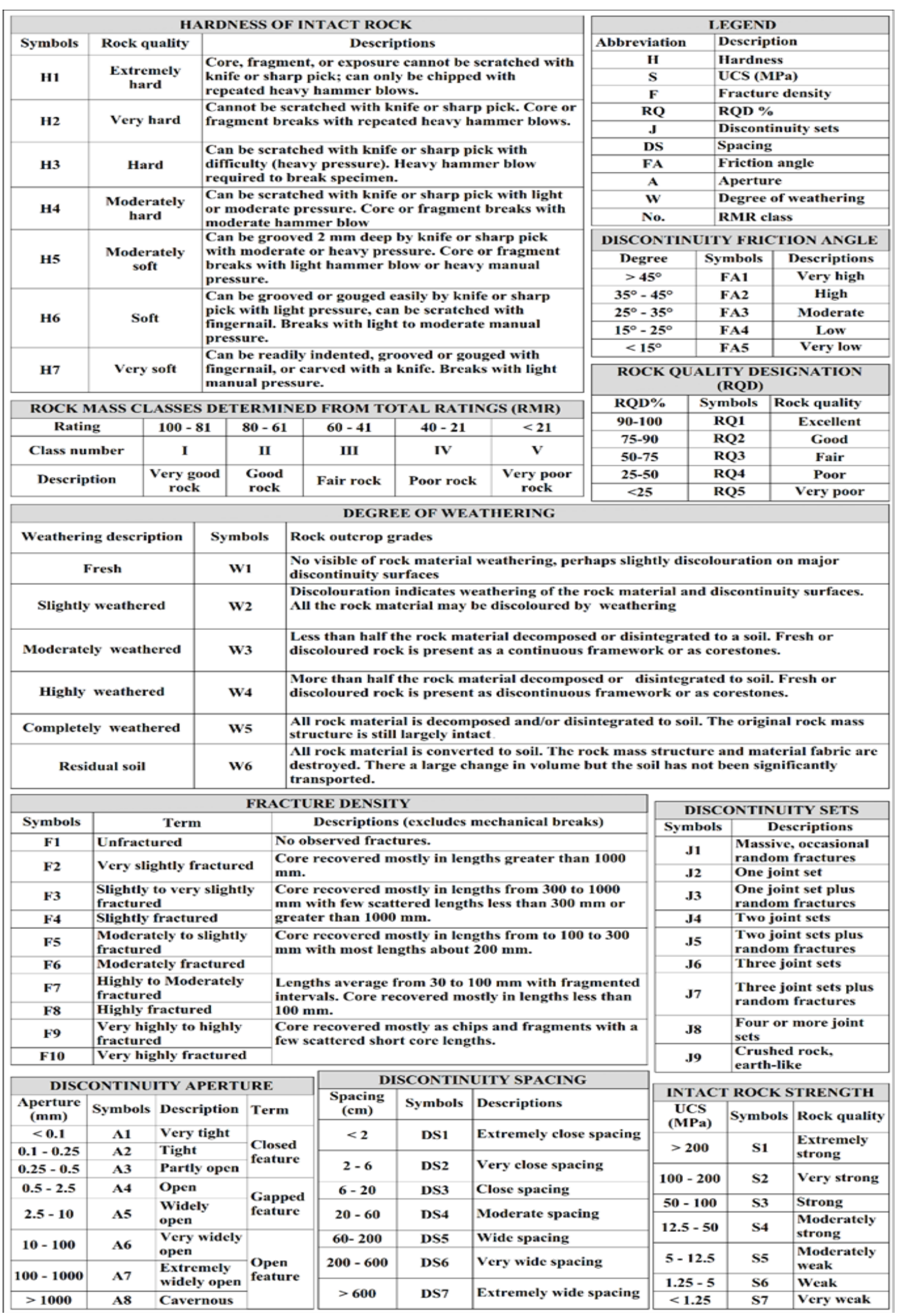


W. A. M. Ogila et al /Egy. J. Pure \& Appl. Sci. 2021; 59(2):15-35

Table 2 The measured values of RMR parameters and classification of the studied rock masses.

\begin{tabular}{|c|c|c|c|c|c|c|c|c|c|c|}
\hline Formation & Rock type & UCS & $\mathrm{RQD}$ & $\begin{array}{c}\text { Spacing of } \\
\text { Discontinuities }\end{array}$ & $\begin{array}{c}\text { Condition of } \\
\text { Discontinuities }\end{array}$ & $\begin{array}{l}\text { Groundwate } \\
\text { r conditions }\end{array}$ & $\begin{array}{l}\text { Discontinuities } \\
\text { properties } \\
\text { (strike and Dip) }\end{array}$ & $\begin{array}{l}\text { RMR } \\
\text { rating }\end{array}$ & $\begin{array}{c}\text { Rock mass } \\
\text { class }\end{array}$ & Description \\
\hline $\begin{array}{l}\text { Aheimer } \\
\text { Formation }\end{array}$ & Sandstone & 7 & 17 & 15 & 20 & 15 & -5 & 69 & II & Good rock \\
\hline Qiseib Formation & Sandstone & 7 & 13 & 15 & 20 & 15 & -5 & 65 & II & Good rock \\
\hline Malha Formation & Sandstone & 7 & 13 & 15 & 20 & 15 & -5 & 65 & II & Good rock \\
\hline Galala Formation & Marl & 7 & 8 & 10 & 20 & 15 & -15 & 45 & III & Fair rock \\
\hline & Dolomite & 12 & 20 & 10 & 25 & 15 & -5 & 77 & $\|$ & Good rock \\
\hline Wata Formation & $\begin{array}{l}\text { Dolomitic } \\
\text { limestone }\end{array}$ & 12 & 20 & 10 & 25 & 15 & -5 & 77 & II & Good rock \\
\hline $\begin{array}{l}\text { Minia and Thebes } \\
\text { Formations }\end{array}$ & Limestone & 12 & 17 & 10 & 25 & 15 & -5 & 74 & II & Good rock \\
\hline
\end{tabular}

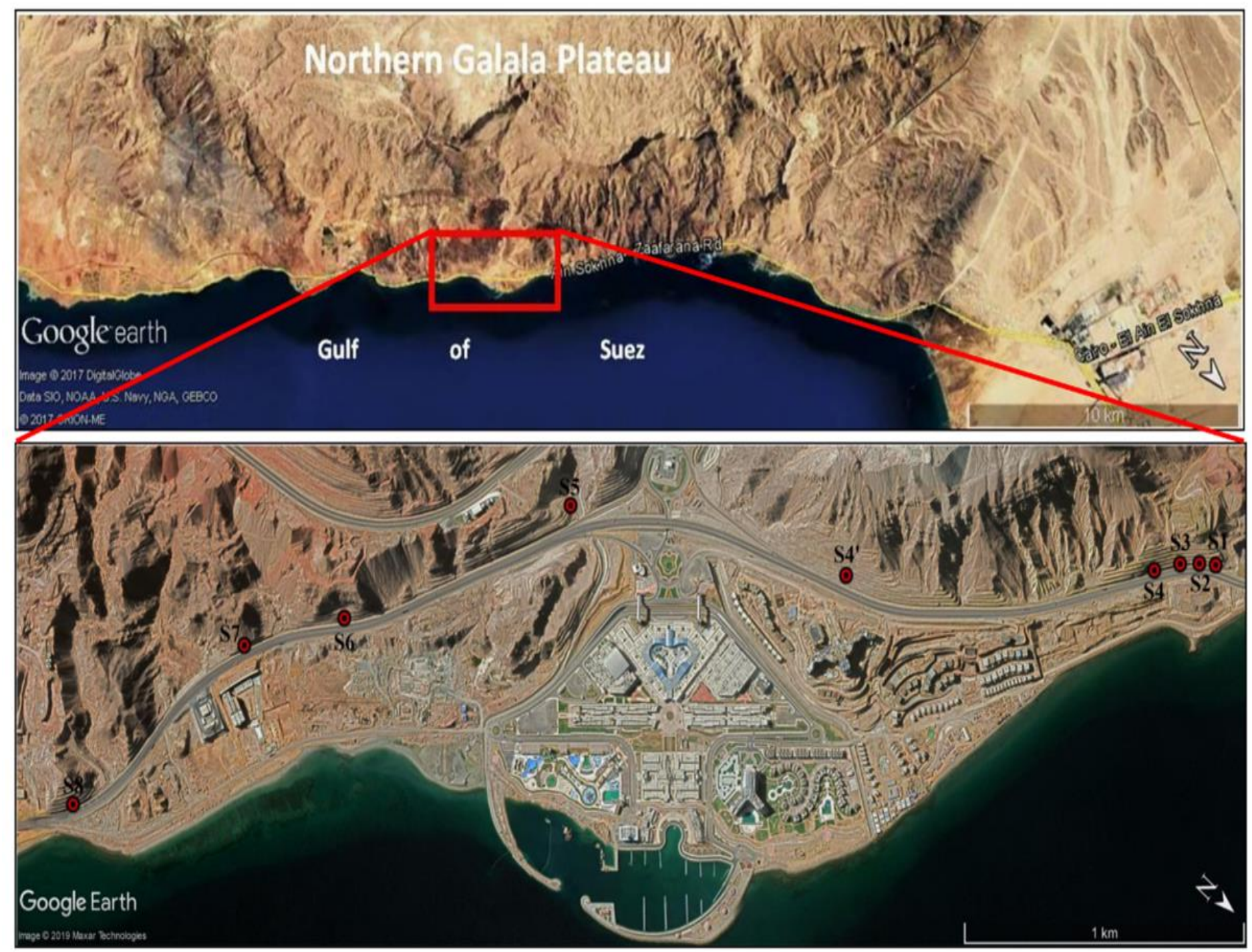

Fig. 4 Google $\mathrm{e}^{\mathrm{TM}}$ image showing the nine locations of discontinuity survey stations along Ain Sukhna-Zafarana highway 


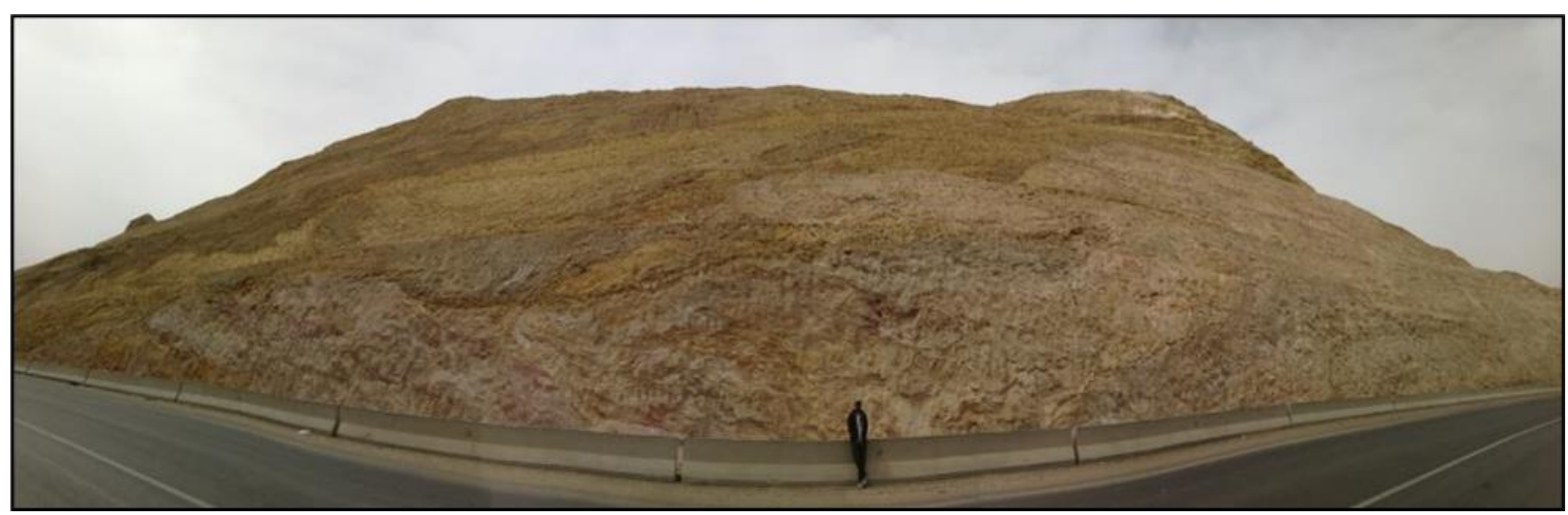

Fig. 5 Field panoramic view of the existing rock cut slope in different rock masses along station no. (4)

\subsection{Kinematic analysis of discontinuities}

The slope faces along the studied stations produce different styles of slope failures due to the presence of unfavorable discontinuities with respect to the orientation of slope cuts. The strike and dip directions of the planes of discontinuities and the cut slopes are plotted using Rocscience ${ }^{\mathrm{TM}}$ Dips V. (6.008) software to identify the possible patterns of slope failures. Shear strength of discontinuities is identified empirically by means of the Barton-Bandis criterion ${ }^{[26]}$ which is considered as a significant parameter for the analysis. The rock cut angles of the studied cut slopes are ranging between $(1 \mathrm{H}: 4 \mathrm{~V}) 75^{\circ}$ and $(1 \mathrm{H}: 10 \mathrm{~V}) 85^{\circ}$. The basic friction angle along the discontinuity planes is $30^{\circ}$ for a slightly weathered wall according to the tilting table test in the field. Interpretation of lower hemisphere stereographic projection of plotted data and site inspection shows major concerns related to critical joint sets orientations and slope face trends, Figs. 6 to 8 . Based on the kinematic analysis, three types of potential failures were recognized which are planar, wedge, and toppling failures.

\subsubsection{Planar Failure}

A planar failure can possibly occur if a discontinuity trend is parallel or sub-parallel (within $\pm 20^{\circ}$ ) to the cut slope strike, with an angle less than that of the slope angle, and greater than that of the friction angle of the failure plane ${ }^{[13]}$. In this study, the planar failure can be expected to occur frequently in the existing rock cut slopes where the conditions of planar failure are fulfilled in the moderately to highly fractured rock units, Fig. 6a. At some places, planar failure has already occurred after the slope excavation, because the cut slope is controlled by a major fault $\left(F_{1}\right)$ of a parallel strike to the excavated slope face, Fig. 6a. Planar failure is expected to occur in all stations except station no. 8. The stereonet plot shows that the most unfavorable conditions for planar failure are controlled by discontinuities $\mathrm{J}_{1}, \mathrm{~J}_{2}, \mathrm{~J}_{3}$ and $\mathrm{J}_{4}$, Fig. $6 \mathrm{~b}$.

\subsubsection{Wedge failure}

A wedge failure may take place when a line of intersection of two discontinuities, forming a wedgelike block plunges in the same direction of the cut slope with an amount gentler than the slope angle but greater than the friction angle along the failure planes ${ }^{[13]}$. Furthermore, the plunge of the line of intersection is daylighted between the toe and the crest of the slope ${ }^{[13]}$.

Wedge failure is expected to occur frequently in the rock cut slopes where the conditions of wedge failure are fulfilled in the highly fractured sandstone and shale series. At some places along Ain Sukhna-Zafarana highway, small wedge failures are observed in the existing rock cut slopes controlled by two intersecting fractures, Fig. 7a. Wedge failure is also expected to occur in all stations along the studied highway with small size blocks. The stereonet plot reveals that the most unfavorable condition for wedge failure is controlled by intersection of discontinuities $J_{1}$ and $J_{2}$, Fig. $7 \mathrm{~b}$.

\subsubsection{Toppling failure}

A toppling failure may result when the unfavorable discontinuity sets are closely spaced parallel or subparallel along strike (within $\pm 10^{\circ}$ ) and steeply dipping into the slope face ${ }^{[13]}$. This failure comprises a series of slabs or blocks of rock mass that overturn or rotate about a fixed base plane. Block toppling is expected to occur frequently in the rock cut slopes where the conditions of toppling failure are fulfilled in the jointed sandstone and shale series, Fig. 8a. At some places, toppling failures are well developed in the existing rock cut slopes which are controlled by sub-vertical and 
and closely spaced joint sets dipping into the slope face. Toppling failure is expected to occur at stations no. $(4,5,6,7$ and 8$)$. The stereonet plot reveals that the most unfavorable condition for toppling failure results from planes of weakness formed by discontinuities $J_{1}, J_{2}$ and $J_{3}$, Fig. 8 b.
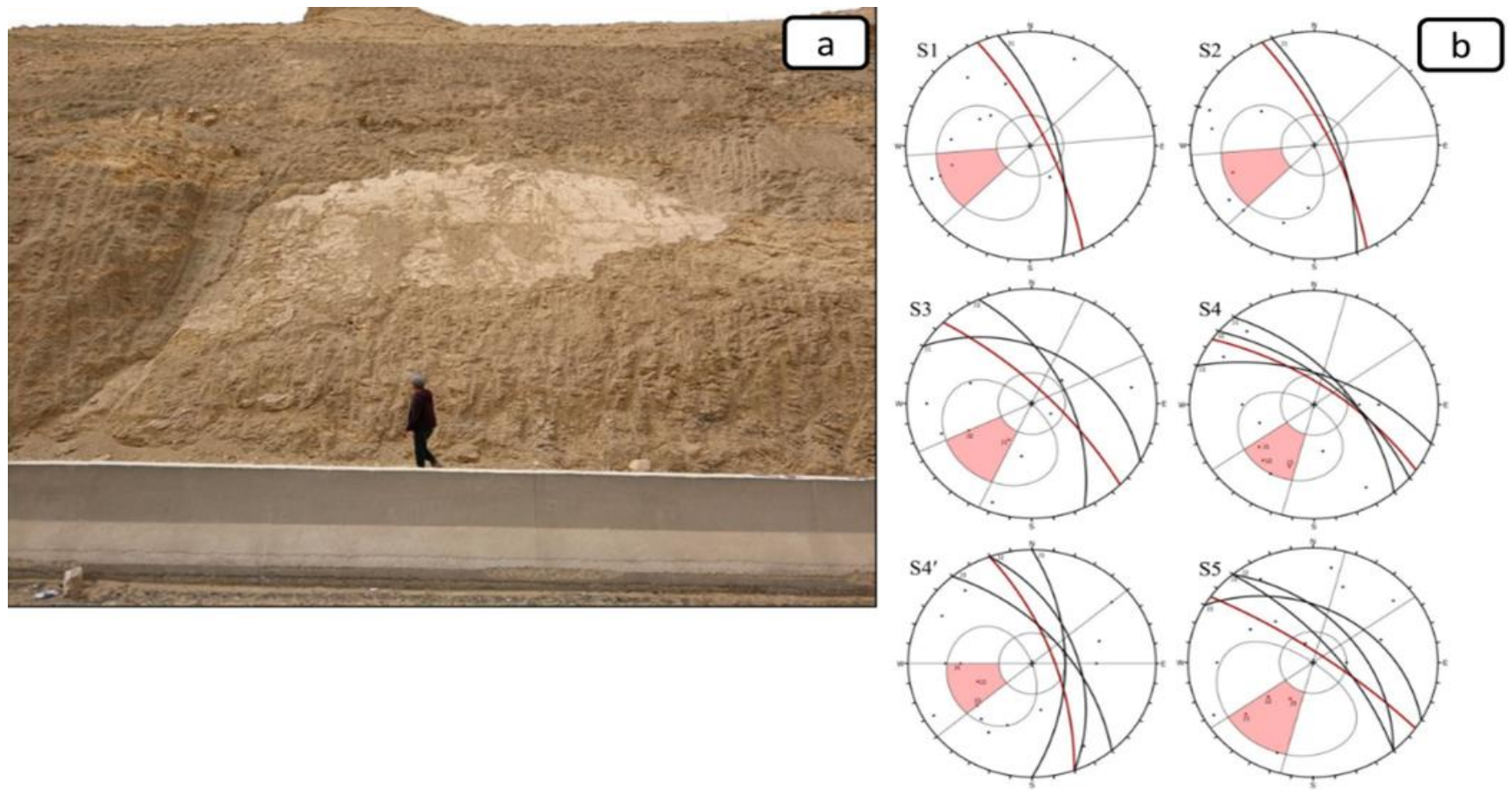

Fig. 6 Field photograph (a) showing the planar failure along the existing rock cut slope controlled by major fault $\left(F_{1}\right)$ at station no. (4). Kinematic analysis (b) of the planar failure at the studied stations. The bold red arc is slope data (dip amount and dip direction), bold black arc is unfavorable discontinuities, black point is the discontinuities pole projection, red point is critical discontinuities pole projection, the gray circle represents friction angle of discontinuities and red area represents the critical zone for planar failure.
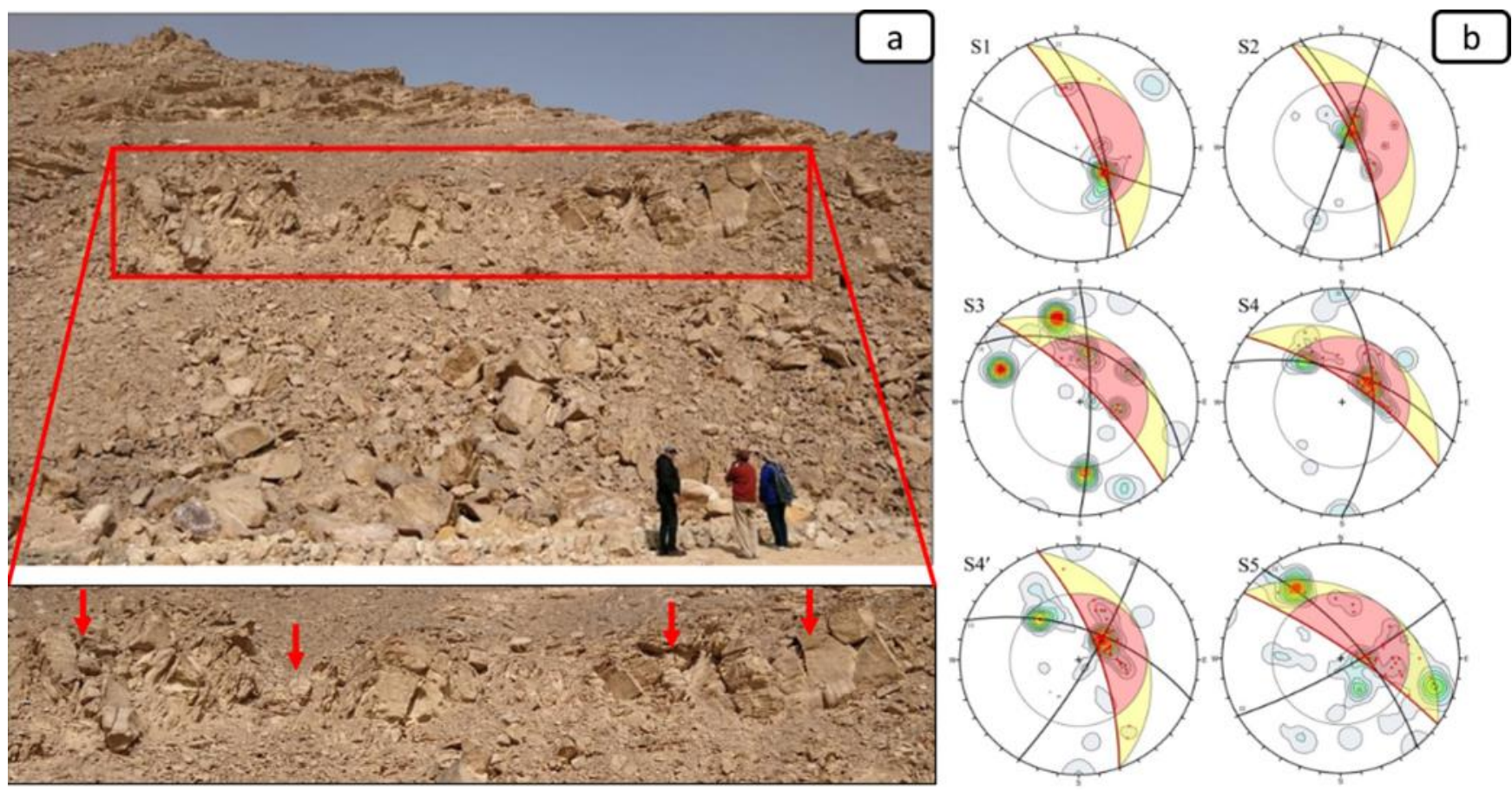

Fig. 7 Field photograph (a) showing the small wedge failures in the upper part within the existing rock cut slope at station no. (4'), the red arrows indicate the locations of wedges. Kinematic analysis (b) of the wedge failure at the studied stations. The bold red arc is slope data, bold black arc is unfavorable discontinuities, black point is the measured discontinuities pole projection, red point is critical discontinuities pole projection, the gray circle represents friction angle of discontinuities and red area represents the critical zone for wedge failure 

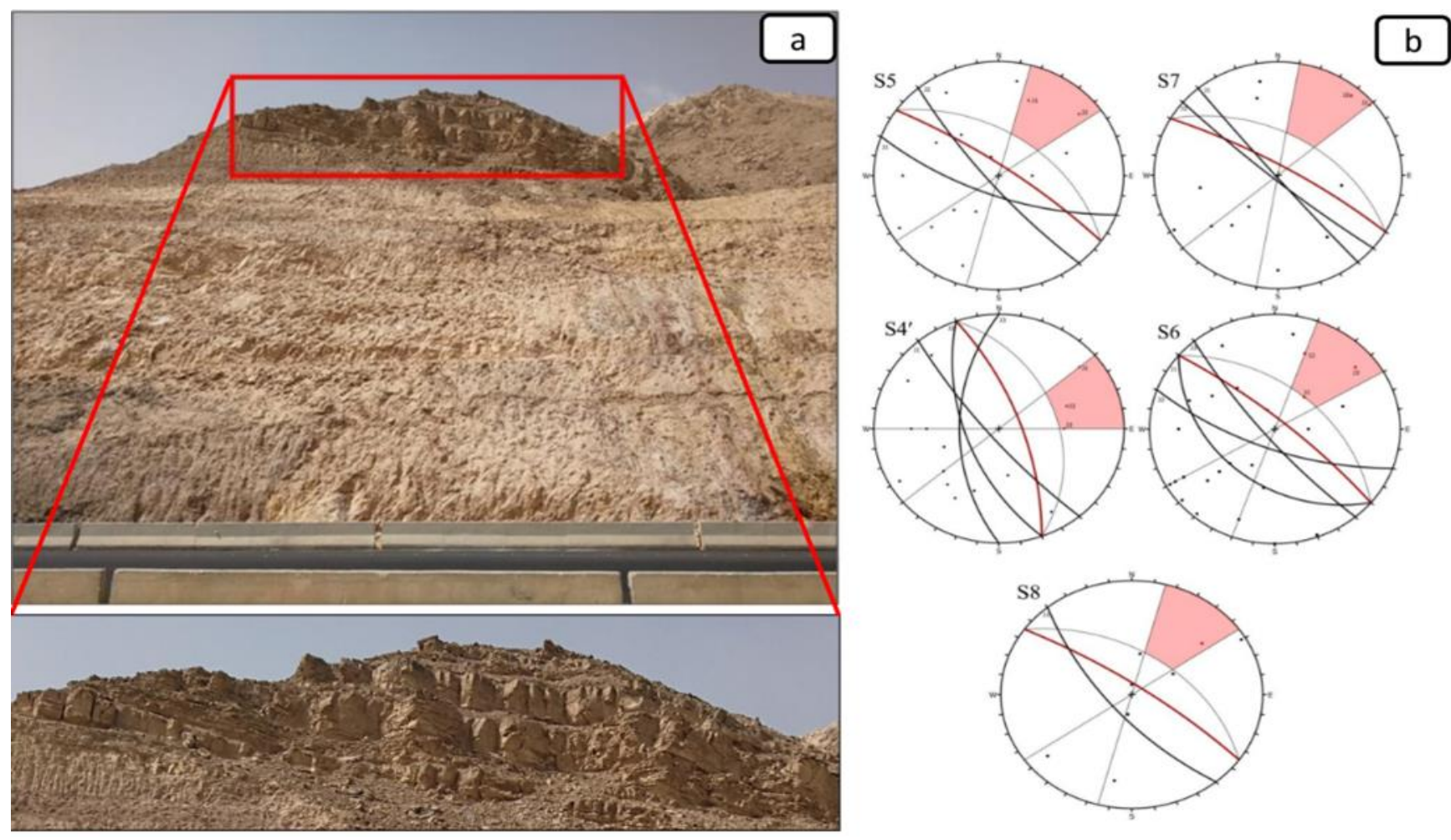

Fig. 8 Field photograph (a) of the potential toppling failure in the upper part of the slope within the existing rock cut at station no. (4'). Kinematic analysis (b) of the toppling failure at studied stations. The bold red arc is slope data, bold black arc is unfavorable discontinuities, black point is the measured discontinuities pole projection, red point is critical discontinuities pole projection, the gray circle represents friction angle of discontinuities and red area represents the critical zone for toppling failure

\subsection{Deterministic analysis}

Deterministic analysis for slope stability is classified under the Limit Equilibrium Methods (LEM) ${ }^{[27,28]}$. This method is typically used to determine the factor of safety (FS) for the expected slope failures ${ }^{[29]}$. The deterministic analysis was carried out using the RocPlane $\mathrm{V}$. (2.029) and SWedge V. (4.080) softwares for planar and wedge failures, respectively. The present study revealed that the geometry of all planar failures within the existing cut slopes, represented by RocPlane, is usually controlled by one set of fractures, Fig. 9. On the other hand, all possibilities of critical wedges within different slope geometries were identified using sWedge, revealing that they are frequently controlled by two intersecting discontinuity sets, Fig. 10. It should be noted that due to the large number of identified wedge failures at the studied stations, it is difficult to represent all these possibilities. A power weight for critical wedge failures was selected based on contour lines zonation analyzed by SWedge program, Fig. $7 \mathrm{~b}$. The input parameters

of this analysis are the unit weight of rocks, slope height, slope angle and slope direction of cut slope, dip amount and dip direction of discontinuity planes, cohesion (c), friction angle ( $\phi)$, water condition, and seismic acceleration. In this investigation, the analyses are performed under different water conditions from dry to wet states, in order to compare the output results for each slope profile, since water infiltration can negatively affect slope stability ${ }^{[30]}$. The basic friction angle of the studied rock masses forming the slope faces is considered an important parameter of stability analysis, where the estimated value of friction angle is $30^{\circ}$ (friction angle of slightly weathered different rock units). The effect of seismic loading on the slopes is applied in terms of the peak ground acceleration (Gulf of Suez area) with a horizontal component value of 0.15 which has a negative effect on the safety factor.

The cut slopes were analyzed considering both normal or present condition (static condition) and seismic or earthquake condition (dynamic condition) stability analyses at dry and saturated conditions. In this study, the analysis revealed that the cut rock 
slopes have high values of safety factor in dry static and dynamic conditions. These values decrease dramatically with the presence of water (saturated conditions) in most cut rock slopes. The calculated FS of planar and wedge planes for the dry and saturated conditions are presented in Tables 3 and 4, respectively. The calculated FS in the case of dry cut slopes in static condition ranges from 0.93 to 1.89 for planar failure planes and from 1.25 to 2.48 for wedge failure planes. This means that the cut slopes are most probably stable in the static condition except one planar failure station no. (4) which is already slided down on site, Fig.6a. Based on the FS values of dry dynamic conditions, some unstable zones of
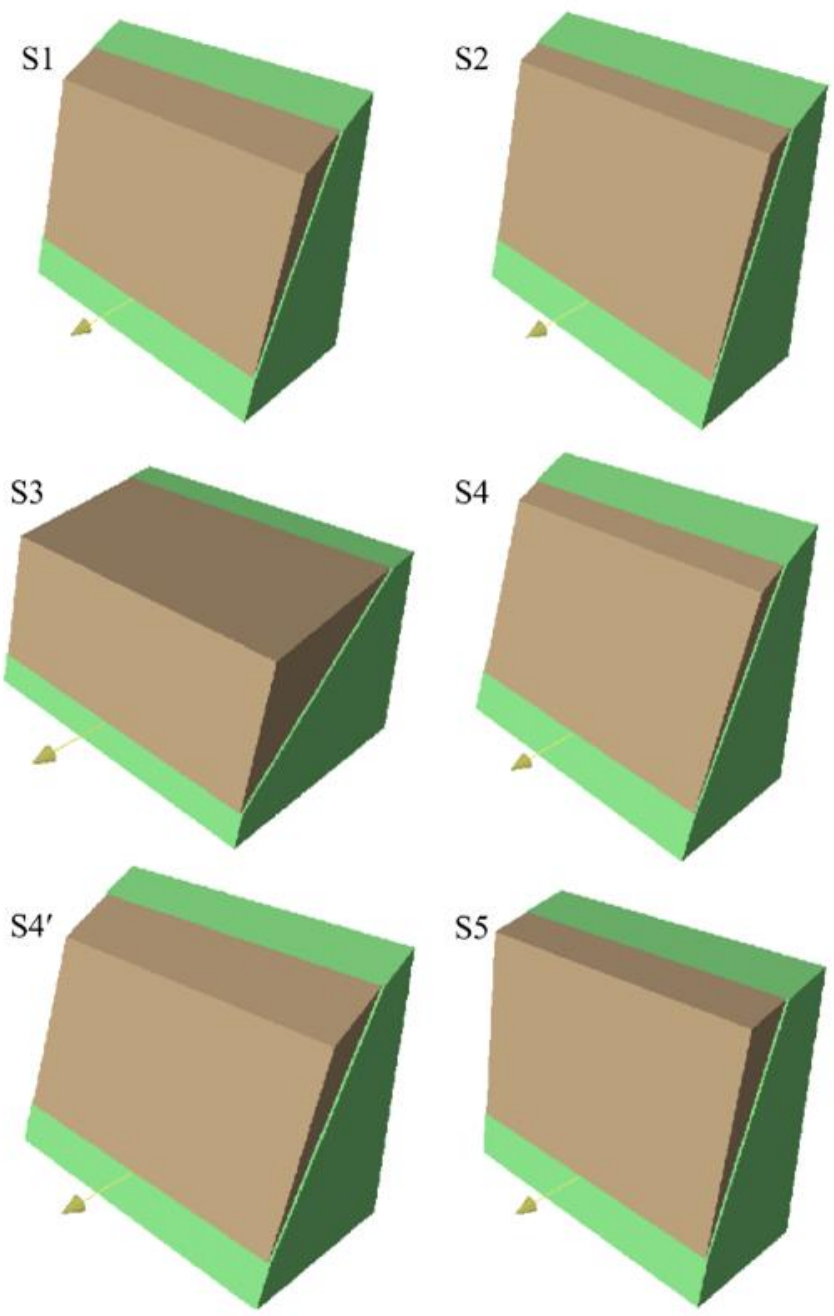

Fig. 9 Three-dimensional (3D) deterministic analysis of the critical planar failure at the different studied stations planar failures are observed at studied stations no. ( 1 2, 4 and 5), whereas most of the wedge failures are in stable condition except the failures at the station no. (5 and 8). When the saturated condition is considered whether, in static or dynamic conditions for the cut slopes, the calculated FS is significantly reduced to be less than unity in most cases of both failure types as expected. This instability is mostly due to the reduction of shear strength and cohesion properties of rocks forming the slopes, which in turn lead to decreasing the friction angles. In this unfavorable condition, the failures are likely to occur during the high rainstorm events of the winter season which are considered as one of the external factors that helps to trigger these failures.
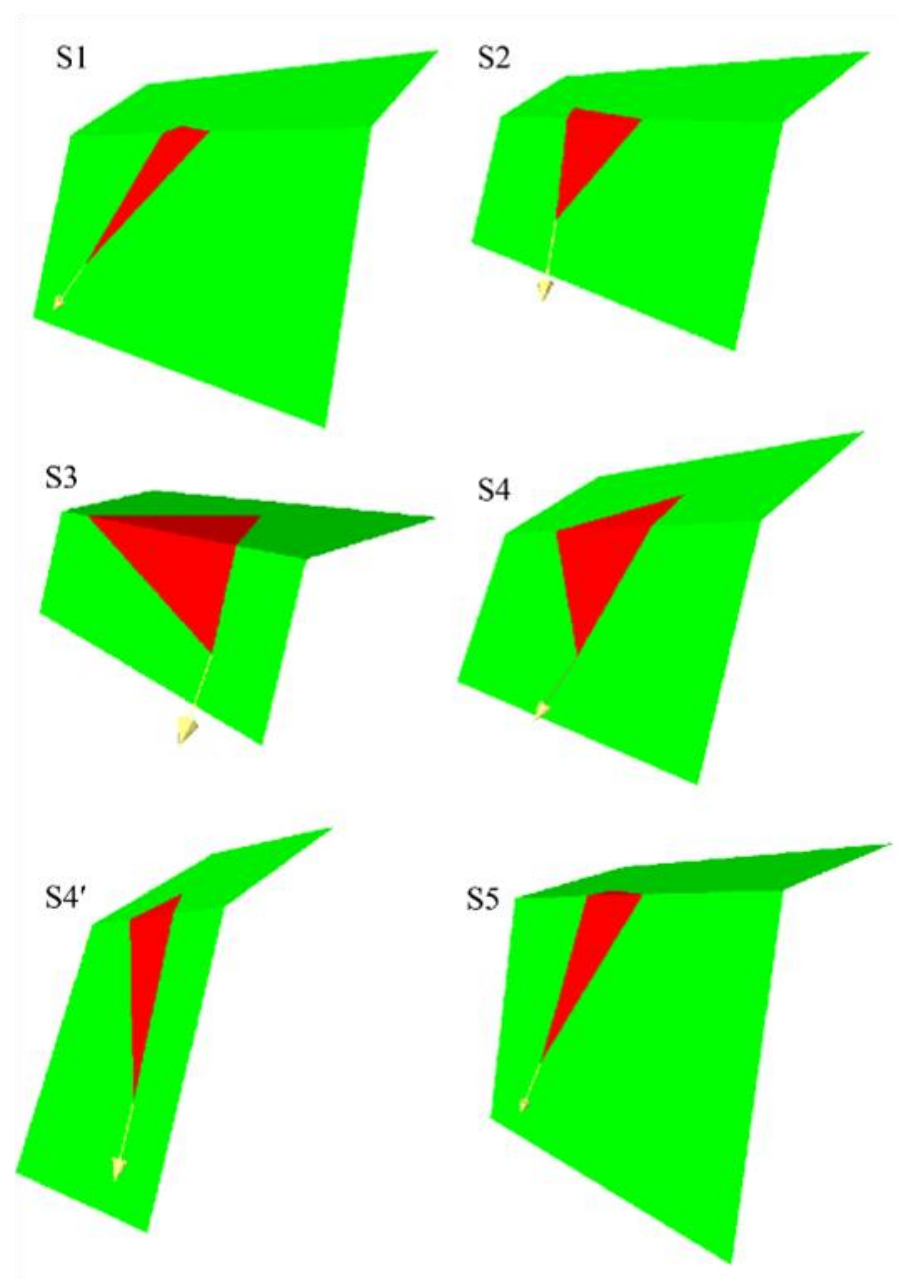

Fig. 10 Three-dimensional (3D) deterministic analysis of the critical wedge failure at the different studied stations 
Table 3 Unfavorable discontinuities and FS comparison for the planar failures under static and dynamic conditions.

\begin{tabular}{|c|c|c|c|c|c|}
\hline \multirow{2}{*}{ Station } & \multirow{2}{*}{ Planar slide surface (Dip/Dip direction) } & \multicolumn{2}{|c|}{ Static condition } & \multicolumn{2}{|c|}{ Dynamic condition } \\
\hline & & FS (dry) & FS (wet) & FS (dry) & FS (wet) \\
\hline S1 & $J_{1} 66 / 075$ & 1.23 & 1.04 & 1.05 & 0.88 \\
\hline S2 & $\mathrm{J}_{1} 70 / 070$ & 1.27 & 1.02 & 1.11 & 0.96 \\
\hline S3 & $\mathrm{J}_{1} 40 / 030$ & 1.89 & 1.82 & 1.65 & 1.45 \\
\hline S4 & $\mathrm{J}_{2} 65 / 040$ & 0.93 & 0.72 & 0.86 & 0.66 \\
\hline S4' & $\mathrm{J}_{1} 60 / 090$ or $\mathrm{J}_{3} 60 / 050$ & 1.54 & 1.36 & 1.32 & 1.16 \\
\hline S5 & $\mathrm{J}_{1} 70 / 050$ & 1.32 & 1.17 & 0.82 & 1.01 \\
\hline S6 & $\mathrm{J}_{4} 70 / 050$ & 1.42 & 1.25 & 1.24 & 1.10 \\
\hline S7 & $\mathrm{J}_{3} 70 / 050$ & 1.55 & 0.86 & 1.37 & 0.71 \\
\hline
\end{tabular}

Table 4 Unfavorable discontinuities and FS comparison for the wedge failures under static and dynamic conditions

\begin{tabular}{llllll}
\hline \multirow{2}{*}{ Station } & \multirow{2}{*}{ Wedge slide surfaces (Dip/Dip direction) } & \multicolumn{2}{l}{ Static condition } & \multicolumn{2}{l}{ Dynamic condition } \\
\cline { 3 - 6 } & & FS (dry) & FS (wet) & FS (dry) & FS (wet) \\
\hline S1 & $J_{1} 66 / 075$ and $J_{2} 80 / 205$ & 1.53 & 1.36 & 1.33 & 0.89 \\
S2 & $J_{1} 70 / 070$ and $J_{2} 89 / 110$ & 2.36 & 2.24 & 2.02 & 0.95 \\
S3 & $J_{1} 40 / 030$ and $J_{2} 80 / 090$ & 2.39 & 2.36 & 1.95 & 1.50 \\
S4 & $J_{1} 60 / 090$ and $J_{2} 60 / 020$ & 2.31 & 2.26 & 2.15 & 0.23 \\
S4 & $J_{1} 60 / 020$ and $J_{2} 80 / 120$ & 2.38 & 2.28 & 2.02 & 0.79 \\
S5 & $J_{1} 70 / 050$ and $J_{2} 80 / 150$ & 1.25 & 1.15 & 1.08 & 0.84 \\
S6 & $J_{1} 80 / 020$ and $J_{2} 72 / 110$ & 1.85 & 1.71 & 1.59 & 0.28 \\
S7 & $J_{1} 65 / 080$ and $J_{2} 80 / 360$ & 2.48 & 2.39 & 2.12 & 0.62 \\
S8 & $J_{1} 80 / 050$ and $J_{2} 75 / 010$ & 1.34 & 1.13 & 1.16 & 0.71 \\
\hline
\end{tabular}

\subsection{Rockfall analysis (rockfall simulation)}

Rockfall is one of the most common geohazards or landslides which particularly occurs in mountainous terrains. The term rockfall is used herein to describe the movement of a single or multiple rocks or boulders downward a slope. It is defined as the free falling, or bouncing, or rolling of individual or a few rock blocks and boulders ${ }^{\left[{ }^{31]}\right.}$ that are detached from the bedrock. Ritchie [32] described these motion modes, and explaining that they substantially depend on the mean slope gradient, Fig. 11. Rock block motion is a fast movement considered as a combination of fall, slide, impact, rebound, and rolling ${ }^{[33]}$. Because of their high speed and kinetic energy, rockfall can be widely accepted as a significantly destructive mass movement resulting in major damage.

Trajectographic analysis is used in the numerical modeling and assessment of the rockfall hazards at some selected profiles along the existing road within the study area. These profiles are located along the mountainous road that connects the Galala resort at the coastal area and the Galala city at the plateau surface, and are named A-A (Permo-Triassic), B-B (Malha), C-C (Galala), D-D (Wata), and E-E (Eocene), Fig. 12. The profiles represent the higher rock cut slopes within the Permo-Triassic, Cretaceous and Eocene rock units which characterize the different types of North Galala rock masses, Fig. 13. The geometries of the existing side slopes are $1 \mathrm{H}: 4 \mathrm{~V}$ and $1 \mathrm{H}$ : $10 \mathrm{~V}$ with berm width ranges between $0.5 \mathrm{~m}$ to $2 \mathrm{~m}$ every $6 \mathrm{~m}$ of slope height, Fig. 13.

In this model, the initial conditions of motion (detachment point and initial velocity, $\mathrm{m} / \mathrm{s}$, at $\mathrm{t}=0$ ) and the coefficients of restitution values are selected based on the laboratory and in-situ field studies in the previous literature ${ }^{[34,35]}$. Normal and tangential coefficients of restitution are the most significant parameters in rockfall analysis which reflect the 
retarding capacity of the slope surface influencing rockfall behavior. Two-dimensional (2D) rockfall simulation is executed along five selected profiles along the rock cut slopes to define the block trajectories, runout distance, kinetic energy and bounce height of the blocks. This investigation is based on the numerical analysis that was carried out by using computer software Rocscience ${ }^{\mathrm{TM}}$ RocFall v. 4.058, Fig. 14. The geological, geometrical, and engineering properties of both source and propagation areas are considered based on site conditions, Fig. 13.
The numerical simulation is carried out using the equations of rigid body motion to calculate velocity and bounce behavior of the rock fragments as it travels down at foot slope area. For the rockfall simulation, the seed area (source area of blocks) for the slope is selected particularly at the slope crest (back slope) and mid-slope areas along cut slope segments, Fig. 15a and 15b. Another significant source for block falling can be the highly fractured rocks on the slope faces. The propagation area (blocks path area) is selected along the cut slope profile under the seed area, Fig. 15b.

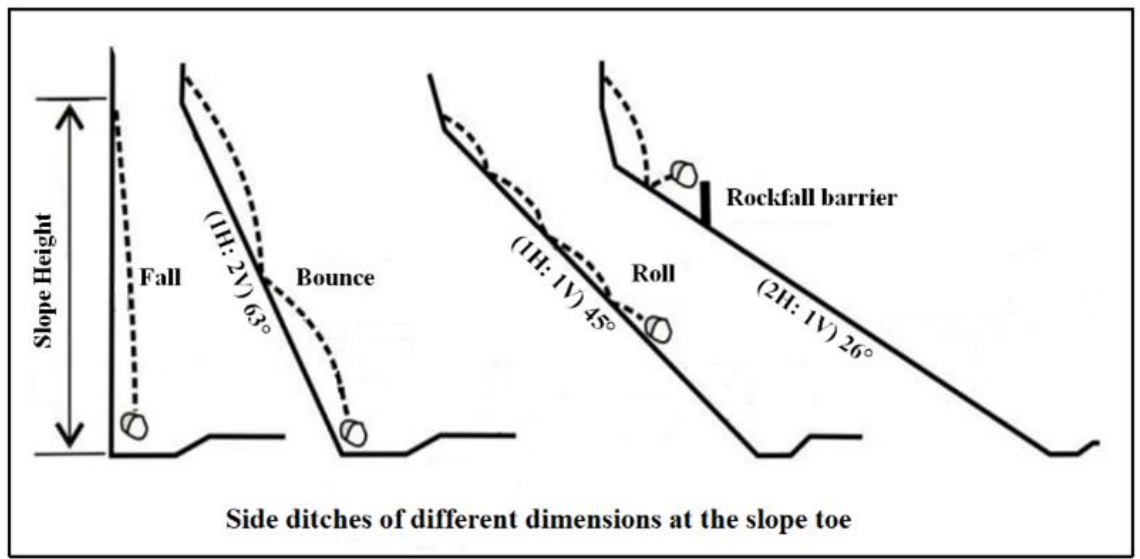

Fig. 11 The rockfall motion modes and suggested protection barrier (modified from ${ }^{[32]}$ )
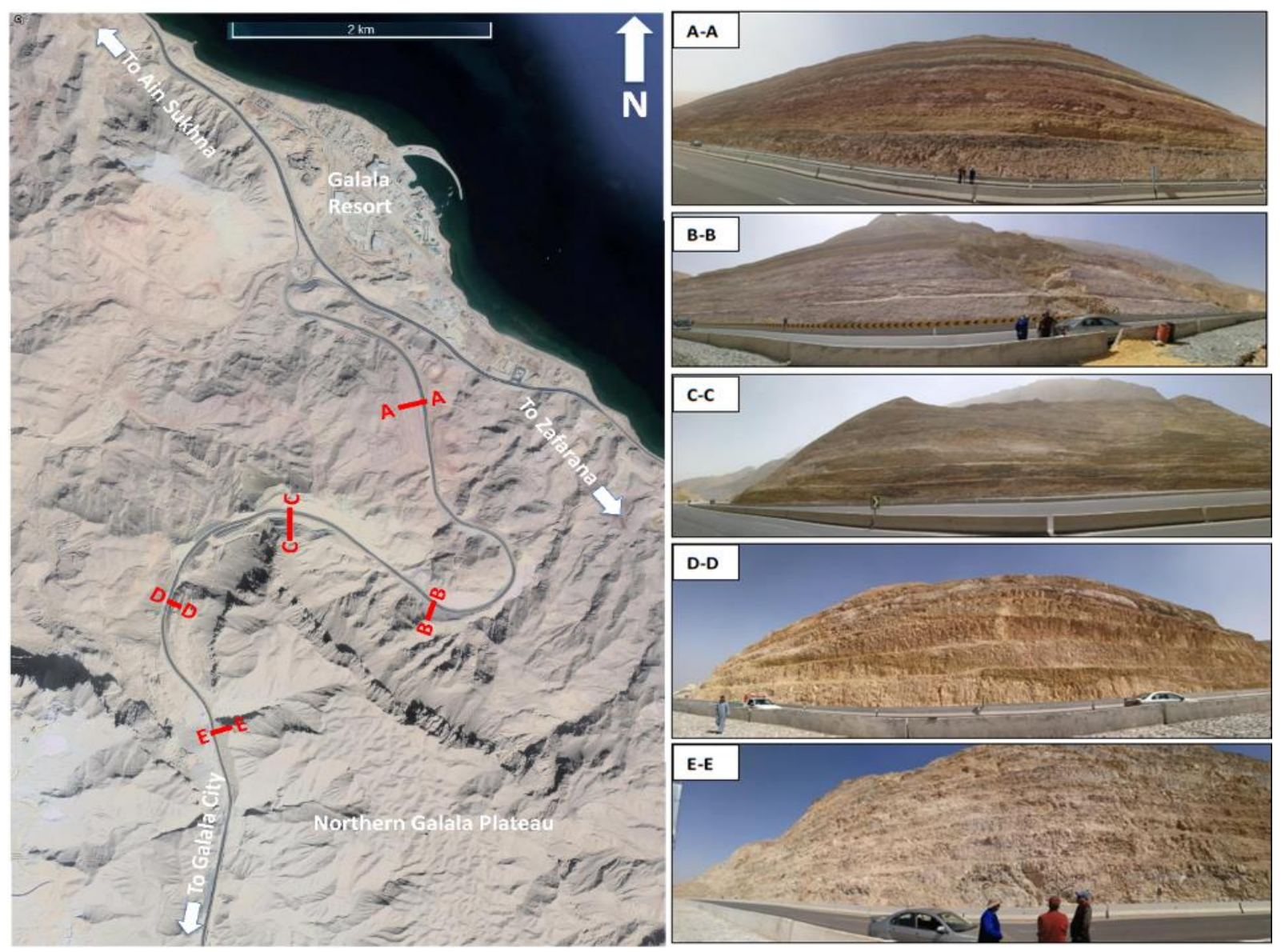

Fig. 12 Location map of the five studied rockfall profiles (A-A, B-B, C-C, D-D, and E-E) 
W. A. M. Ogila et al /Egy. J. Pure \& Appl. Sci. 2021; 59(2):15-35

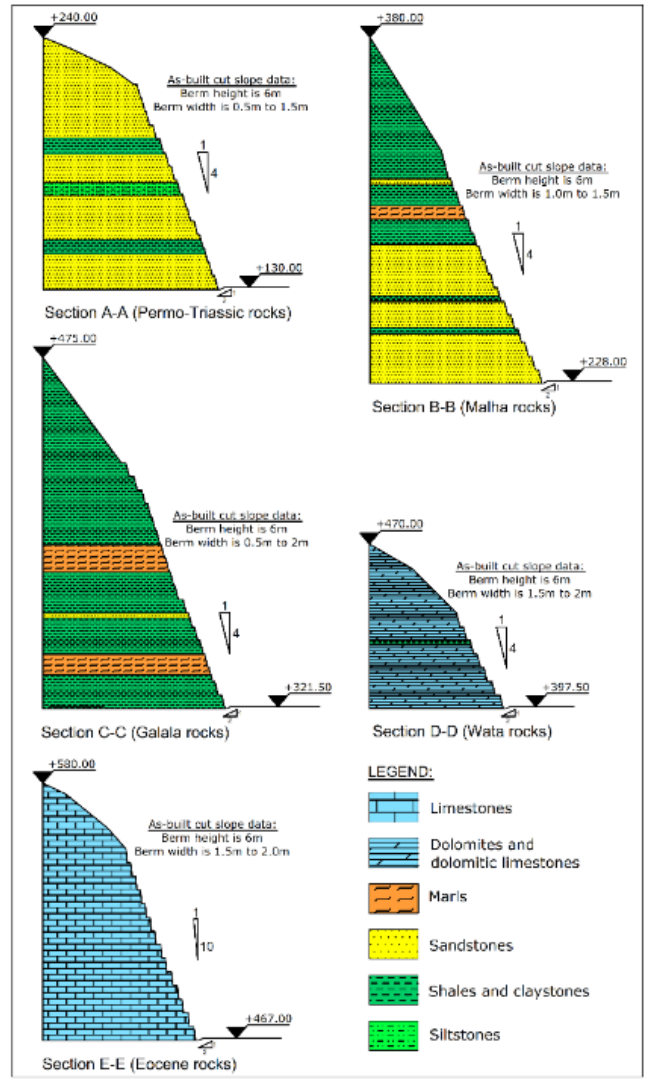

Fig. 13 Geologic cross-sections and geometry for the existing rock cuts along the studied road

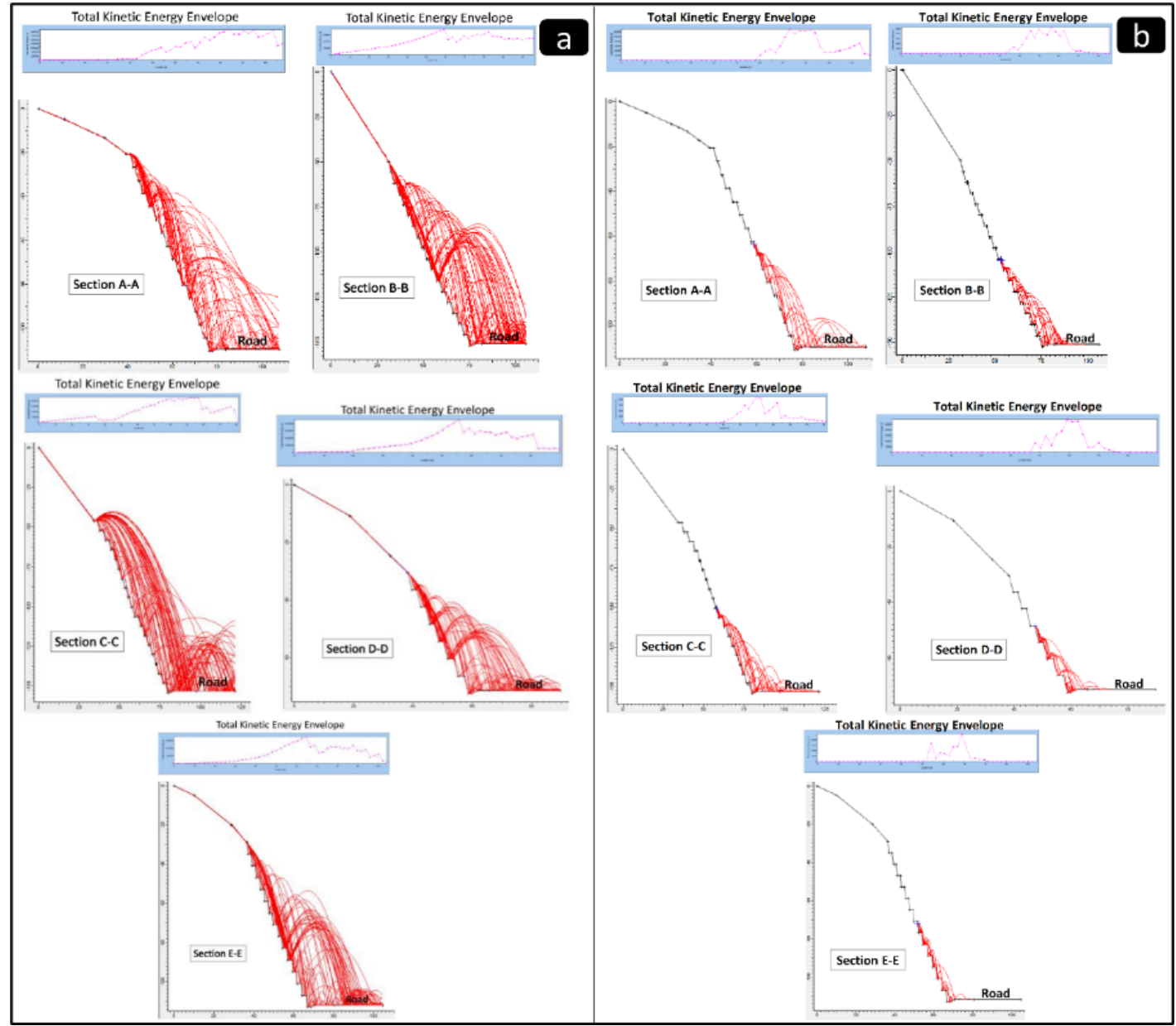

Fig. 14 Rockfall analysis and total kinetic energy envelope at (a) slope crest seeders (back slope area), and (b) mid-slope seeders of the different studied sections 


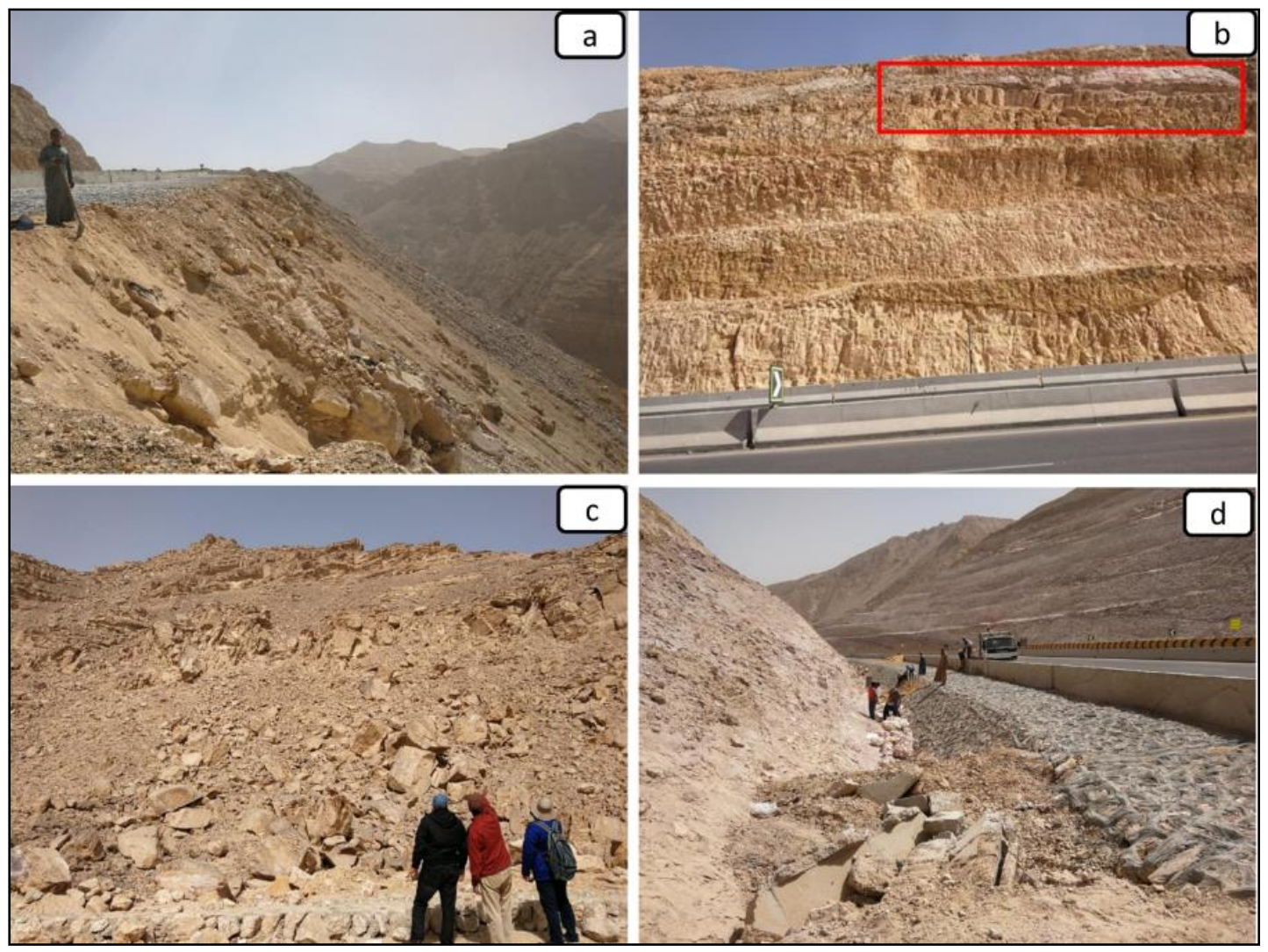

Fig. 15 Site photographs showing (a) the rock fragments and dump materials at the upper part of slope (seed area), (b) the hanging rock blocks in the slope face (propagation area) at the upper part (the red rectangle), (c) The dominant block size which ranges between $0.5 \mathrm{~m}^{3}$ to $3 \mathrm{~m}^{3}$ and (d) the constructed side ditch at the slope toe with width of $2.5 \mathrm{~m}$

The retarding capacity of slope surface is affected by the lithology of the material covering the cut slope surface. Consequently, the selected restitution coefficient takes into consideration the geometric and rock type characteristics of boulders and talus deposits at the source area. In this analysis, different rock units such as limestone and sandstone form the slope body within propagation area. The restitution coefficients $\left(R_{n}=0.487\right.$ and $\left.R_{t}=0.910\right)$ for rock slopes as well as the friction angle of $30^{\circ}$ are considered for different rock units along the rock cut slopes based on the methods suggested by ${ }^{[34-36]}$.

Once the movement of a rockfall is initiated, its falling behavior is controlled by cut slope geometry, slope properties, and lithological properties of source and propagation areas. In this investigation, the upper part of slope is covered by a mixture of rock fragments Fig. 15a and the slope face is composed of hanging blocks with a dominant size ranging between 0.5 and 3 $\mathrm{m}^{3}$ that is considered as a rockfall source area, Fig. 15b and $15 \mathrm{c}$. Larger rock blocks produce higher kinetic energy and can cause more extensive damage than smaller ones. The roundness of these blocks is mostly angular with few subangular edged blocks. All blocks are derived from the slope body composed generally of limestone and sandstone, Fig.13.

For the propagation area, slope geometry is composed of several berms and slopes (a step-like shape, Fig. 13). These berms in slopes act as a transition zone for falling blocks that reduce impact and rebound, which in turn change blocks velocities. The block trajectories (height and length of block flight), runout distance, kinetic energy and bounce height are commonly controlled by the lithological properties of the propagation area. In general, high amounts of kinetic energy generated via falling blocks can be dissipated by the soil cover and soft rock as shale on slope surface which leads to the decrease of their trajectory height and intensity. Surfaces covered in talus material, scree or gravel absorb an extensive amount of the energy of the falling rock and in many cases, will probably stop it completely. 
These mechanical conditions create low damage during rockfall, whereas the clean hard unweathered rock slopes with a smooth surface represent the greatest rockfall damage because they do not retard the movement of the falling or rolling blocks to any significant degree as in the case of this study.

The characteristics of rockfall trajectories (height and length of flight) allowed us to design and optimize positioning of protection works such as barriers and fences. Construction of rockfall barriers is a remedial measure for long runout distance and high bounce of falling blocks. In such cases, the protection barriers must be higher than the boulders trajectories that should be placed at most of the hazardous area.

Kinetic energy, impact velocity, runout distance and bounce heights of the rockfall trajectory are significant factors when designing rockfall barriers and mitigation measures. The runout distance (coverage distance) for rockfall of the slope crest seeders ranges from $25 \mathrm{~m}$ to $43 \mathrm{~m}$, and from $12 \mathrm{~m}$ to $30 \mathrm{~m}$ for mid-slope seeders which are considered as moderate to high travel distance. It is important to note that the roll movement is observed at the upper segment of natural slope (seed area), while the fall and bounce movements are dominant along the cut slopes within the propagation area, Fig. 14. The rockfall simulation revealed that the bounce heights of falling blocks from slope crest ranges between $40 \mathrm{~m}$ and $90 \mathrm{~m}$, Fig. 14a, while the bounce heights of the mid-slope area ranges from $14 \mathrm{~m}$ to $35 \mathrm{~m}$, Fig. 14b. The total kinetic energy produced by falling blocks is a function in the velocity which is increased by slope height as the velocity of block increase. However, the maximum total kinetic energy for the proposed profiles of fallen rocks along the cut slopes reach $2375 \mathrm{KJ}$ as calculated at the studied profiles, Table 5 and Fig. 14. These outcomes can be taken as a preliminary value for the design consideration of rockfall protection barriers.

Unfortunately, the executed side ditch at the slope toe is not enough to catch the falling rocks as well as its width ranging between $2.5 \mathrm{~m}$ and $3.5 \mathrm{~m}$, Fig. 15d. There are also no barriers or retaining structures to protect the road from the rockfall events which need wider side ditch at foot slope. Based on the above, the rockfall barriers or fences are suggested to be constructed at the upper part and middle part of the cut slopes with a height of about $2 \mathrm{~m}$ to $10 \mathrm{~m}$ based the bounce heights that produced from rockfall simulation, Table 5 . This should be effective and more economic than constructing rockfall barriers at foot slopes, Fig. 16. For ravelling rocks on the cut slopes, the side ditch at the slope toe is highly recommended which is acting as a catchment area for falling rocks preventing them from reaching the highway, residential area or other facilities in front of the slope. The designed dimensions (depth and width) of the typical side ditch is controlled by the coverage distance of rockfall analysis. The most effective permanent rockfall protecting system for the highways is the construction of a catch ditch at the toe of the slope, therfore, it is recommended that the base of the catch ditch should be covered by a layer of gravel with a thickness not less than $0.3 \mathrm{~m}$ to absorb the impact energy of the falling rocks ${ }^{[37]}$.

Table 5 Total kinetic energy (KE) and suggested barrier heights at different profiles

\begin{tabular}{lcccc}
\hline \multirow{2}{*}{ Section } & \multicolumn{2}{c}{ Seed area at slope crest } & \multicolumn{2}{c}{ Seed area at mid-slope } \\
\cline { 2 - 5 } & $\begin{array}{c}\text { Max. Total KE } \\
(\mathrm{KJ})\end{array}$ & $\begin{array}{c}\text { Suggested barrier } \\
\text { heights }(\mathrm{m})\end{array}$ & $\begin{array}{c}\text { Max. Total KE } \\
(\mathrm{KJ})\end{array}$ & $\begin{array}{c}\text { Suggested barrier } \\
\text { heights }(\mathrm{m})\end{array}$ \\
\hline Section A-A (Permo-Triassic rocks) & 1500 & 10 & 65 & 3 \\
Section B-B (Malha rocks) & 2000 & 7.5 & 55 & 2 \\
Section C-C (Galala rocks) & 2375 & 3.5 & 4.25 & 2.5 \\
Section D-D (Wata rocks) & 900 & 4 & 30 & 2 \\
Section E-E (Eocene rocks) & 1750 & 6 & 25 & 3 \\
\hline
\end{tabular}




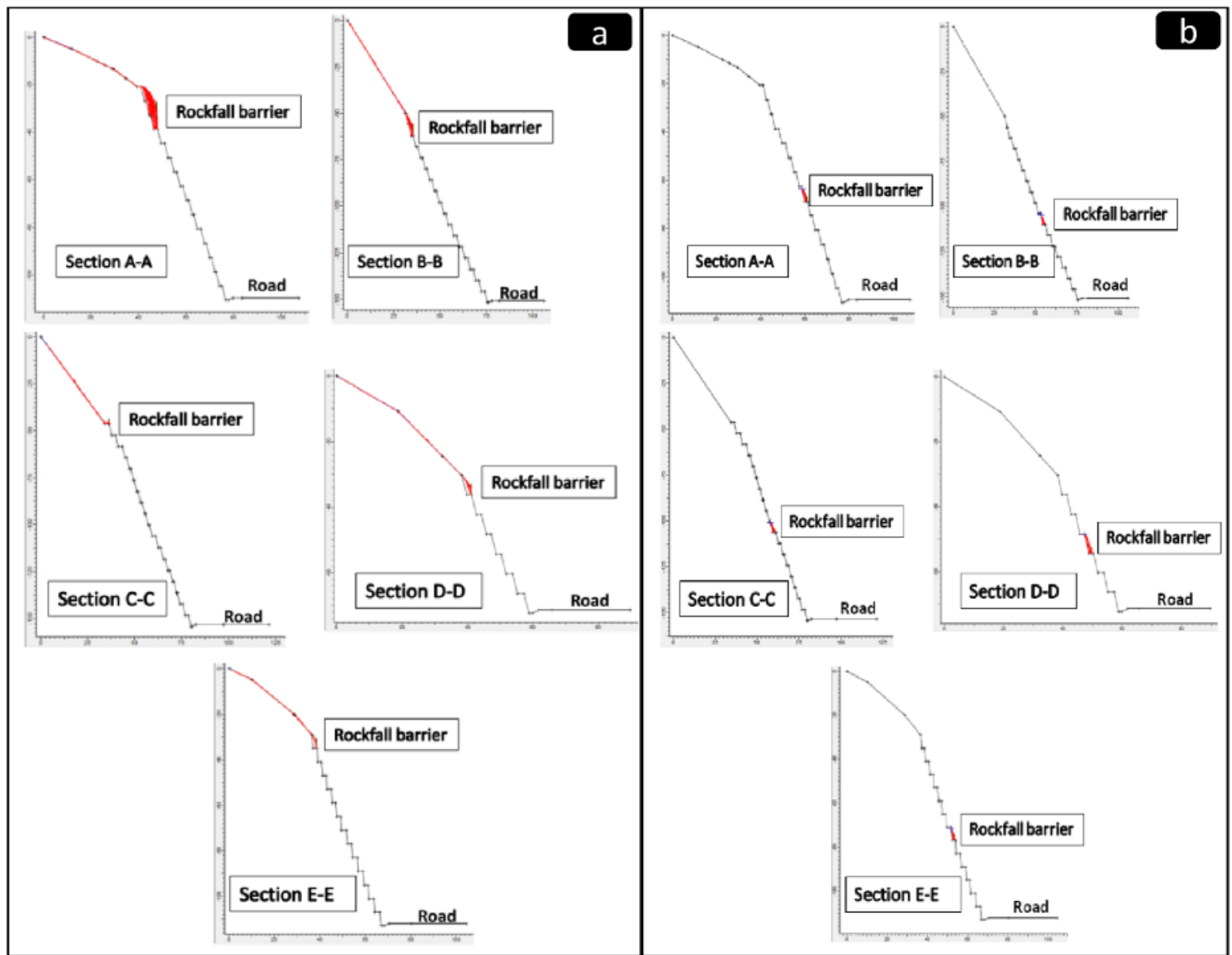

Fig. 16 Proposed locations for rockfall barriers or fences at (a) the upper part and (b) middle part of the studied cut slopes

\section{Discussion}

\subsection{Rockfall hazard zonation}

Based on slope stability interpretation of the kinematic, deterministic and rockfall analyses, the studied road is clearly divided into several risk zones, Fig. 17. These proposed risk zones are divided according to the site inspection and encountered engineering geological conditions of different rock masses along the cut slopes. The studied road is divided into three categories low, moderate and highrisk zones of rockfall. On the map, low risk zones indicate low rockfalls potential to road (that is characterized by low rock cut height $<5 \mathrm{~m}$ or no cut, low potential of rockfall or slope failures based on the site inspection, no slope failures observed along the cut slopes), moderate risk zones indicate moderate slope instability and rockfalls impact along the road (that is characterized by moderate rock cut height ranges from $5 \mathrm{~m}$ to $12 \mathrm{~m}$, moderate potential of rockfall or slope failures based on the site inspection, moderately poor blasting excavation, moderate intensity of hanging blocks on slope face and back slope area, slope failures or rockfalls observed along few cut slopes), and the highly dangerous segments of the road indicate the road subjected to intensive rockfall or rock sliding events(that is characterized by high rock cut height $>12 \mathrm{~m}$, high potential of rockfall or slope failures with high kinetic energy (average 1705 $\mathrm{KJ})$, poor basting excavation, high intensity of hanging blocks on slope face and back slope area, low safety factor (average 0.86), slope failures or rockfalls observed along several cut slopes).

\subsection{Stability and protection measures}

The main objective of slope stabilization is to increase the resistance forces against the driving forces which in turn increases the FS value of cut slopes ${ }^{[38]}$. Protection elements are used to protect the final cut slope from the erosion possesses which act as trigger factors for local slope failures and rockfalls ${ }^{[13]}$. Consequently, the slope stabilization measures mitigate the risk occurrence of different types of landslides. Therefore, the slope stabilization measures can be installed in the 
form of removal works, retaining and flexible barriers, side ditches, and rock bolting. As well as the protection layers, wire mesh and shotcrete, can be recommended for the highly weathered and fractured rock cut slope faces ${ }^{[39]}$.

Removal works (scaling and terming) and reshaping of slopes are inexpensive and effective ways for local slope failures because unstable rocks can be removed before they can fall. Barriers or fences are usually constructed along the cut slopes to catch the rockfalls when they fall down before they reach the road. Some rockfalls barriers or retaining structures are suggested in the study area particularly at the potential rockfall areas, Fig. 16. The recommended retaining walls can be in the form of concrete retaining or flexible rockfall barriers considering the structural design parameters including the kinetic energy values. Based on carried out trajectory analysis (rockfall analysis), the walls must be constructed at the upper and middle parts of the studied slopes in order to protect the road from rockfall hazards, Fig. 16. For raveling rocks on the cut slopes, the side ditch at the slope toe is highly recommended which acts as a catchment area for falling rocks in order to prevent them from reaching the highway or the surrounding residential areas.

Spot or systematic grouted rock bolts are required at the unstable large failure blocks (greter than 5 tones) to keep the slope blocks and rock slabs from downward movement. In the studied cut slopes, a shotcrete and wire mesh are recommended to protect small size failure blocks as observed in Figs. 7, 8 and 15. The slope stability analysis of studied rock cuts revealed that the most of unstable blocks are classified as small sizes unstable planar and wedge failures blocks. To protect and increase the slope cut factor of safety, a reinforced shotcrete layer of maximum $10 \mathrm{~cm}$ thick is suggested to protect these slope cuts and preventing rock failures. The shotcrete and wire mesh can be catching these small blocks and safely preventing slope rock fall. Moreover, weep holes are a very essential drainage system to prevent infiltration through slope discontinuities and reduce the pore pressure effect that can enhance the stability of the final rock cut.

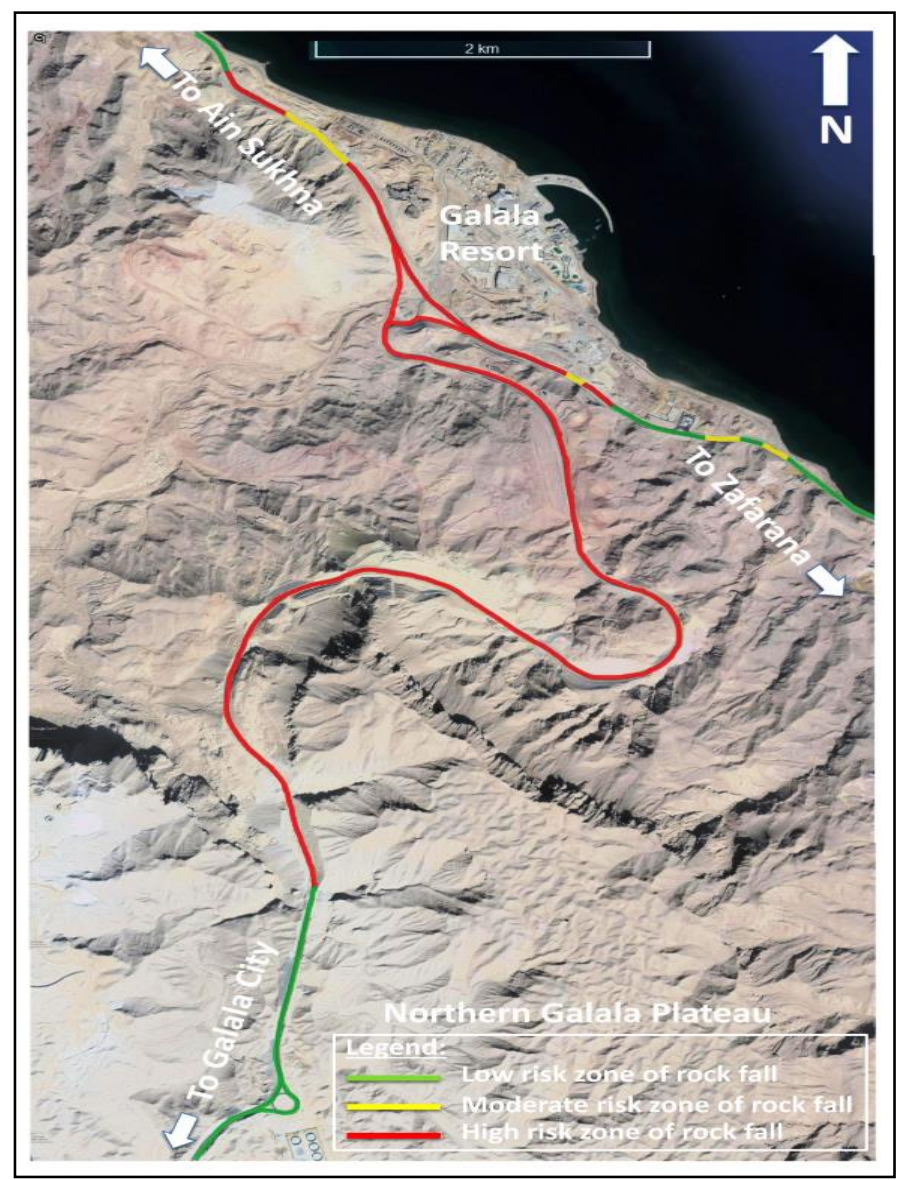

Fig. 17 The hazard zonation map of slope instability and rockfalls 


\section{Conclusions and recommendations}

Excavation works are the most significant considerations in highway and foundation design. The study area is subjected to mass excavations in order to construct new urban areas and roads along the coastal area of the eastern side of the Northern Galala Plateau. The executed side slopes of the Ain SukhnaZafarana highway have produced different types of rock failures due to the presence of unfavorable discontinuities with respect to the cut slope orientation. The discontinuity survey was carried out at nine stations through the existing rock cuts in order to predict the failure mechanisms by using kinematic analysis. The deterministic analysis is used to determine the factor of safety (FS) for each expected slope failure under static and dynamic load at dry and wet conditions. Based on these analyses, planar, wedge, and toppling failures can potentially occur at the upper steep parts of the studied slope profiles. Moreover, the calculated FS for the expected failures is more than unity at most stations in dry static and dynamic conditions and these values are reduced to less than unity in the presence of water (wet conditions) in most cases. So, these rock slope failures seem to occur mainly during the high rainstorm events. Rockfall modeling is constructed along selected profiles to assess the rockfall hazards related to the falling rock blocks and debris. The coverage distance for rockfalls of the studied profiles ranges between $12 \mathrm{~m}$ to $43 \mathrm{~m}$ where the bounce heights of falling blocks ranges between $14 \mathrm{~m}$ to $90 \mathrm{~m}$. The maximum total kinetic energy for the proposed profiles of fallen rocks along the cut slopes reaches up to $2375 \mathrm{KJ}$.

The supporting and protection measures are recommended depending on slope stability analyses, site inspection, and encountered engineering geological conditions of different rock masses. It is highly recommended that the removal works including scaling and terming should be carried out at the cut slope faces and upper part of the slopes to remove the hanging blocks and debris. Rock bolts are proposed to support the unstable large failure blocks (greater than 5 tones) in order to increase the resisting force and FS under dry and saturated dynamic conditions. Side ditches at slope toe and rockfall barriers or flexible fences at the upper and middle parts of the existing slopes are highly required to prevent the falling blocks to reach the constructed roads or adjacent urban areas
Wire mesh and shotcrete are recommended at the highly weathered and fractured rock cut slope faces as protection layers to resist erosion and degradation processes. Also, weep holes are a very essential drainage system to prevent infiltration through slope discontinuities and reduce the pore pressure effect that can enhance stability of final rock cuts.

\section{Acknowledgments}

The authors would like to thank Dar Al-Handasah Consultants (Shair and Partners) for allowing the use of the Rocscience ${ }^{\mathrm{TM}}$ software packages.

\section{References}

1. Chen, J., Zhao, Y. and Shan-Yang, (2019). Research on the Classification of slope stability state based on the method of vectorization attribute circle. J. IEEE Access., 7: 74879 74889. DOI: 10.1109/ACCESS.2019.2920984.

2. Wang, H. L., Xu, W. Y. and Shao, J. F. (2014). Experimental researches on hydro-mechanical properties of altered rock under confining pressures. J. Rock Mech. Rock Eng., 47(2): 485 - 493. DOI:10.1007/s00603-013-0439-y.

3. Pan, Y., Wu, G., Zhao, Z. and He, L. (2020). Analysis of rock slope stability under rainfall conditions considering the water-induced weakening of rock. J. Comput. Geotech., 128: 103806.DOI: 10.1016/i.compgeo.2020.103806.

4. Grasselli, G. (2005). 3D Behaviour of bolted rock joints: Experimental and numerical study. Inter. J. Rock Mech. Min. Sci., 42(1): 13 - 24. DOI:10.1016/j.ijrmms.2004.06.003.

5. Chai, X. J. and Hayashi, S. (2005). Effect of constrained dilatancy on pull-out resistance of nails in sandy. J. Ground Improvement, 9(3) : 127 $\quad 135 . \quad$ DOI: 10.1680/grim.2005.9.3.127.

6. Mona, L. and Alf, K. (2006). New methods for tunnel investigation. In: Sustainable Underground Concepts. Publication No.15. Norwegian Tunnelling Socity, $71-75$.

7. Leroueil, S. (2001). Natural slopes and cuts: movement and failure mechanisms. J. Géotech., $\quad$ 51(3): $197 \quad-\quad 243$. DOI:10.1680/geot.2001.51.3.197. 
8. Pradhan, S. P. and Siddique, T. (2020). Stability assessment of landslide-prone road cut rock slopes in Himalayan terrain: A finite element method based approach. J. Rock Mech. Geotech. Eng., 12(1): 59 - 73. DOl: 10.1016/i.jrmge.2018.12.018.

9. Sutejo, Y. and Gofar, N. (2015). Effect of area development on the stability of cut slopes. J. Procedia Eng., 125: 331 - 337. DOI: 10.1016/i.proeng.2015.11.071.

10. Harabinová, S. (2017). Assessment of slope stability on the road. J. Procedia Eng., 190: 390 - 397. DOI: 10.1016/j.proeng.2017.05.354.

11. Stockton, E., Leshchinsky, B. A., Olsen, M. J. and Evans, T. M. (2019). Influence of both anisotropic friction and cohesion on the formation of tension cracks and stability of slopes. J. Eng. Geol., 249: 31 - 44. DOl: 10.1016/j.enggeo.2018.12.016.

12. Ahangar-Asr, A., Faramarzi, A. and Javadi, A. A. (2010). A new approach for prediction of the stability of soil and rock slopes. J. Eng. Comput. (Swansea, Wales)., 27(7): 878 - 893. DOI:10.1108/02644401011073700.

13. Hoek, E. and Bray, J. W. (2018). Rock Slope Engineering. Revised $5^{\text {th }}$ Ed., The Institution of Mining and Metallurgy, London. P. 368.

14. Abdallah, A. M. and Adindani, A. (1963). Stratigraphy of Upper Paleozoic rocks, western side of the Gulf of Suez, Egypt. J. Geol. Surv. Mineral Res. Egypt, 25: 1 - 18.

15. Abdallah, A. M., Adindani, A. and Fahmy, N. (1963). Stratigraphy of the Lower Mesozoic rocks, western side of the Gulf of Suez, Egypt. J. Geol. Surv. Mineral Res. Egypt, 27: 1 - 23.

16. Keheila, E. A. (2000). The impact of the Syrian arch system on carbonated facies, stratigraphy and paleogeography of the lower Eocene, north eastern desert, Egypt. Egy. J. Geol., 44(2): 147 - 182.

17. Said, R. (1960). Planktonic Foraminifera from Thebes Formation, Luxor, Egypt. Micropaleontology, 6 (3): $277-286$.
18. Bosworth, W., Stockli, D. F. and Helgeson, D.

E. (2015). Integrated outcrop, 3D seismic, and geochronologic interpretation of Red Sea dikerelated deformation in the Western Desert, Egypt - the role of the 23 Ma Cairo "miniplume". J. Afr. Earth Sci., 109:,107,-,119. DOI: 10.1016/j.jafrearsci.2015.05.005.

19. Khalifa, M. A. and Kandil, A. A. (2004). Contribution to the lithostratigraphy and depositional history of the Upper Cretaceous rock units, Northern Galala, Eastern Desert, Egypt. Ann. Geol. Surv. Mineral Res. Egypt, 27: $213-235$.

20. Saber, S. G. (2012). Depositional framework and sequence stratigraphy of the Cenomanian-Turonian rocks on the western side of the Gulf of Suez, Egypt. Cretaceous Res., 37: $300 \quad-3 \quad 18 . \quad$ DOI: 10.1016/j.cretres.2012.03.008.

21. Bieniawski, Z. T. (1989). Engineering rock mass classification. John Willey and Sons, New York. P 251.

22. Li, D., Wong, L. N. Y., Liu, G. and Zhang, X. (2012). Influence of water content and anisotropy on the strength and deformability of low porosity meta-sedimentary rocks under triaxial compression. J. Eng. Geol., 126: 46 66. DOI: 10.1016/j.enggeo.2011.12.009.

23. Liu, X., Li, D. Q., Cao, Z. J. and Wang, Y. (2020). Adaptive Monte Carlo simulation method for system reliability analysis of slope stability based on limit equilibrium methods. J. Eng. Geol., 264: $105384 . \quad$ DOl: 10.1016/j.enggeo.2019.105384.

24. Liu, S., Su, Z., Li, M. and Shao, L. (2020). Slope stability analysis using elastic finite element stress fields. J. Eng. Geol., 273: 105673. DOl: 10.1016/i.enggeo.2020.105673.

25. Liu, Z., Liu, J., Bian, K. and Ai, F. (2019). Three-dimensional limit equilibrium method based on a TIN sliding surface. J. Eng. Geol., 262: $\quad 105325$.

DOI: 10.1016/j.enggeo.2019.105325. 
26. Barton, N. and Bandis, S. (1990). Review of predictive capabilities of JRC-JCS model in engineering practice. Inter. Symp. Rock Joints. Loen, Rotterdam, Balkema. 603 - 610.

27. Taylor, D. W. (1937). Stability of earth slopes. J. Boston Soc. Civil Eng., 24: 197 246.

28. Bishop, A. W. (1955). The use of the slip circle in the stability analysis of earth slopes. J. Géotechnique., 5: 7 - 17. DOI: 10.1680/geot.1955.5.1.7.

29. Deng, D. (2020). Limit equilibrium solution for the rock slope stability under the coupling effect of the shear dilatancy and strain softening. Int. J. Rock Mech. Min. Sci., 134: 104421. DOI: 10.1016/j.ijrmms.2020.104421.

30. Hou, X., Vanapalli, S. K. and Li T. (2018). Water infiltration characteristics in loess associated with irrigation activities and its influence on the slope stability in Heifangtai loess highland, China. J. Eng. Geol., 234: 27 37. DOI: 10.1016/j.enggeo.2017.12.020.

31. Cruden, D. M. and Varnes, D. J. (1996). Landslides types and processes. In: Turner AK, Schuster RL (Eds.) Landslides: investigation and mitigation, Transportation research board special report. National Academy Press, Washington. 247: 36 - 75.

32. Ritchie, A. M. (1963). Evaluation of rockfall and its control. Highway Res. Record, Washington. 17: 13 - 28.
33. Chiessi, V., D'Orefice, M., Mugnozza, G. S., Vitale, V. and Cannese, C. (2010). Geological, geomechanical and geostatistical assessment of rockfall hazard in San Quirico village (Abruzzo, Italy). J. Geomorph. 119(3):,147,161. DOI: 10.1016/i.geomorph.2010.03.010.

34. Chau, K. T., Wong, R. H. C. and Wu, J. J. (2002). Coefficient of restitution and rotational motions of rockfall impacts. Inter. J. Rock Mech. Min.Sci. 39(1):,69 - 77. DOI: 10.1016/S13651609(02)00016-3.

35. Asteriou, P., Saroglou, H. and Tsiambaos, G. (2012). Geotechnical and kinematic parameters affecting the coefficients of restitution for rock fall analysis. Inter. J. Rock Mech. Min. Sci. 54: 103 - 113. DOI: 10.1016/j.ijrmms.2012.05.029.

36. Richards, L. R., Peng, B. and Bell, D. H. (2001). Laboratory and field evaluation of the normal coefficient of restitution for rocks. ISRM Reg. Symp. EUROCK. 149 - 155.

37. Yu, Y. F., Siu, C. K. and Pun, W. K. (2005). Guidelines on the use of prescriptive measures for rock cut slopes. GEO REPORT No. (161). The Government of the Hong Kong Special Administrative Region. P 31.

38. Razdolsky, A.G. (2009). Slope stability analysis based on the direct comparison of driving forces and resisting forces. International journal for numerical and analytical methods in geomechanics. 33(8): 1123-1134.

39. Wyllie, D. C. and Mah, C. W. (2005). Rock Slope Engineering: civil and mining (4 ${ }^{\text {th }}$ Ed.). Taylor \& Francis Group. New York. P 456. 